\title{
Exploring Futures of the Hindu Kush Himalaya: Scenarios and Pathways
}

\author{
Coordinating Lead Authors \\ Joyashree Roy, Jadavpur University, Kolkata, India, e-mail: joyashreeju@gmail.com \\ Eddy Moors, VU University, Amsterdam, The Netherlands and IHE Delft, The Netherlands, \\ e-mail: e.moors@un-ihe.org \\ M. S. R. Murthy, International Centre for Integrated Mountain Development, Kathmandu, Nepal, \\ e-mail: murthy.manchi@gmail.com (corresponding author)
}

\section{Lead Authors}

Prabhakar S. V. R. K., Natural Resources and Ecosystem Services Group, Institute for Global Environmental Strategies, Hayama, Japan, e-mail: prabhakar@iges.or.jp

Bahadar Nawab Khattak, COMSATS Institute of Information Technology, Abbottabad, Pakistan, e-mail: bahadar@ciit.net.pk

Peili Shi, Institute of Geographic Sciences and Natural Resources Research, Chinese Academy of Sciences, China, e-mail: shipl@igsnrr.ac.cn

Christian Huggel, Department of Geography, University of Zurich, Switzerland, e-mail: christian.huggel@geo.uzh.ch

Vishwas Chitale, International Centre for Integrated Mountain Development, Kathmandu, Nepal, e-mail: vishwas.chitale@icimod.org

\section{Contributing Authors}

Mohan Poudel, REDD Implementation Centre, Govt. of Nepal, Kathmandu, Nepal, e-mail: mohanprasadpoudel@gmail.com

\section{Review Editors}

Laurie Vasily, International Centre for Integrated Mountain Development, Kathmandu, Nepal, e-mail: laurie.vasily@icimod.org

Atiq Rahman, Bangladesh Centre for Advanced Studies, Dhaka, Bangladesh,

e-mail: atiq.rahman50@gmail.com

\section{Corresponding Author}

M. S. R. Murthy, International Centre for Integrated Mountain Development, Kathmandu, Nepal, e-mail: murthy.manchi@gmail.com 


\section{Contents}

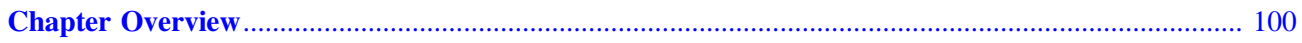

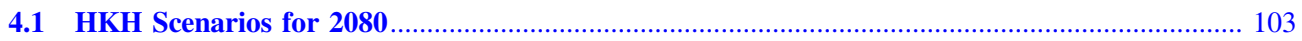

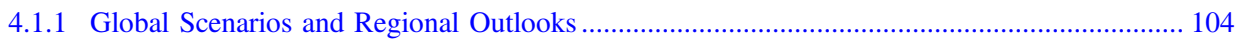

4.1.2 Challenges and Opportunities for the HKH ...................................................................... 105

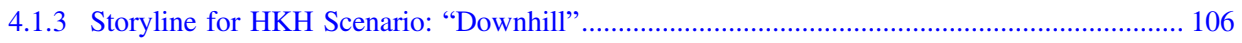

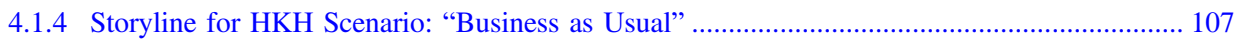

4.1.5 Storyline for HKH Scenario: "Prosperous HKH" ................................................................... 107

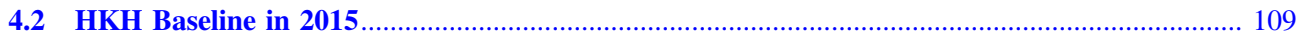

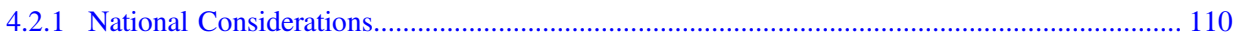

4.3 Tracking Trends and Commitments for 2030: SDG's and NDC's in the HKH...................... 111

4.3.1 Existing Sectoral Commitments Toward 2030 Sectoral/Thematic Considerations................... 111

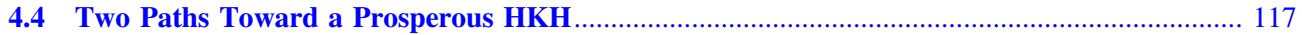

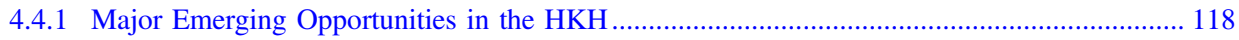

4.4.2 Two Pathways and Distinguishing Actions ......................................................................... 118

4.4.3 Two Pathways but Common Actions ........................................................................................... 122

4.4.4 Actions to Avoid Downhill and Business as Usual (BAU) Scenarios ..................................... 123

4.5 Beyond 2050 to 2080: Knowledge Gaps and Ways Forward .................................................. 123

References

\section{Chapter Overview}

\section{Key Findings}

This is a precarious moment for the Hindu Kush Himalaya (HKH). Environmentally, socially, and economically, there is no single likely future for the HKH. Between now and 2080, the HKH may run downhill, or the region may continue doing business as usual and muddling through, or it may advance toward prosperity.

Evidence-based actions to reduce disaster risk, to mitigate and adapt to climate change and to adopt good governance, are central to ensuring prosperity in the HKH by 2080, as well as collaboration among state and non-state actors. Two potential pathways-large-scale investment in sustainable development with regional cooperation, and bottom-up investment with local and national cooperation-both involve substantial collaboration at different levels (regional, national, or sub-national).

\section{Policy Messages}

To avert the downhill scenario for the HKH in 2080, institutional mechanisms must confront the main challenges and resolve conflicts at various levels, and among various social groups. Globally, actions towards climate change mitigation and adaptation are urgently needed. Regionally, actions for sustainable livelihoods and economic growth should consider maintaining and improving the diversity and uniqueness of transboundary HKH natural assets, socio-cultural richness, ecosystem services as well as the need for political collaboration and information sharing.

If decision-makers, governments, institutions, and communities in the HKH continue business as usual, the HKH will face significant risk. Strategic action must be taken to change continued inadequate implementation of environmental protections; the ongoing suboptimal use of water and biodiversity resources; the continuance of unplanned urbanization in $\mathrm{HKH}$; and the failure to adequately reduce greenhouse gas emissions.

To achieve prosperity in 2080 , it is important to consider two potential pathways for the HKHlarge-scale sustainable development investment with regional cooperation, and bottom-up investment with local and national cooperation. Both paths critically presuppose cooperation and coordination. Large-scale investment would rely on high-level decisions, made across national boundaries, to capitalize on emerging and unique economic opportunities in the regional market. Bottom-up investment would mobilize local and national investments and 
development initiatives, managed across various levels of society and government and with the collaboration of multiple stakeholders.

The two paths toward prosperity in the HKH are not mutually exclusive-they can and need to be integrated. Decision makers may combine elements of either path at various stages, making trade-offs between the benefits and risks associated with different actions at different levels.

To illuminate future uncertainties and inform strategic plans, this chapter presents three qualitative scenarios for the status of the HKH through 2080. The scenarios (Box 4.1) emerged from a participatory visioning exercise for scenario development (also see Sect. 4.1.2) conducted by the chapter team and HIMAP secretariat between January and September 2016. Over six successive workshops, decision makers and scientists representing $\mathrm{HKH}$ countries determined what would constitute a prosperous $\mathrm{HKH}$ scenario for 2080 along with its less desirable alternatives, business as usual and downhill (Fig. 4.1).

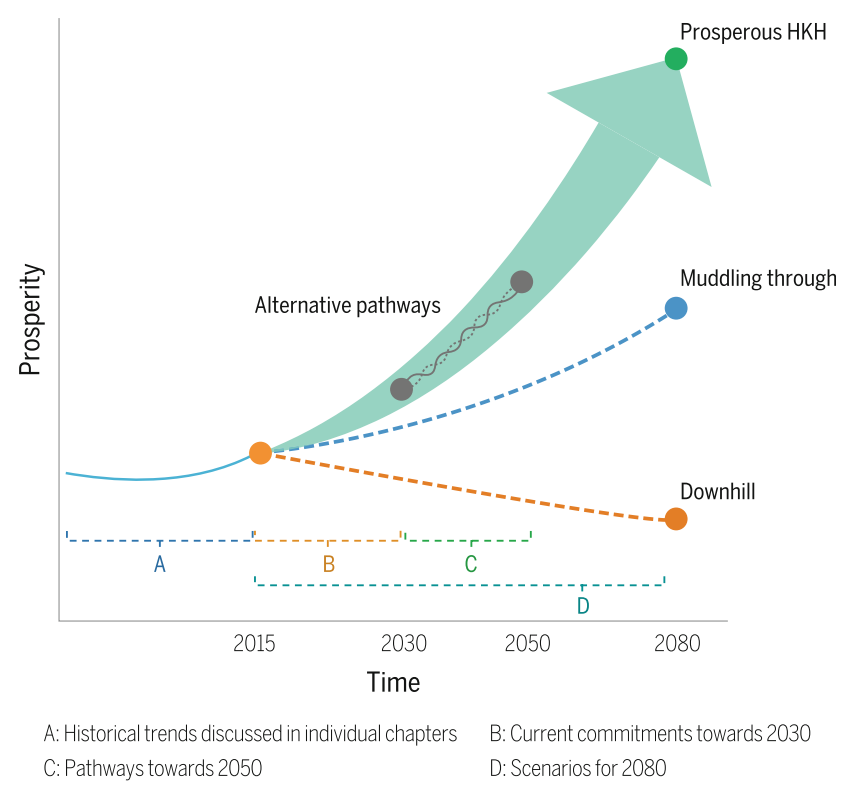

Fig. 4.1 Three scenarios depicting the possible prosperity development for the HKH in 2080: downhill, business as usual, prosperous
Box 4.1 How do scenarios contribute to envisioning the future?

In conventional planning approaches, which are still used in many countries and institutions, one planning period is followed by the next, and each planning period can be relatively independent of the earlier planning periods. This can create gaps and a lack of consistency between consecutive planning phases as the objectives may change drastically from one planning phase to the next. Additionally, the relatively short lifetime of conventional planning periods (5 years), makes them less suitable for exploring uncertainty in future societal and environmental conditions likely to occur in the longer term.

To enable short-term developmental actions to be consistent with longer-term societal and environmental transformation pathways towards a desired future, long-term future scenarios are used. It is important to note that a scenario is not a forecast or prediction; rather it is a plausible story about the future with a logical plot and narrative governing the manner in which events unfold.

Scenario development generally summarizes discourses such as those on poverty, nutrition, food security, and demographic change into a "shared vision" taking into consideration various stakeholders.

No regional quantitative model simulations for future social economic scenarios of the $\mathrm{HKH}$ region have been developed previously. As a result, as part of this overall HIMAP assessment, this chapter team made the first step and developed qualitative scenarios. We facilitated a participatory process by interviewing experts and stakeholders to develop such storylines to help in generating qualitative scenarios for $\mathrm{HKH}$. Also, given the unique character of the $\mathrm{HKH}$ a regional level scenario development process allowed for a shared vision for the future which individual country-level scenarios cannot. Therefore, the HKH scenarios are presented in the form of storylines based on inputs of all scenario-development workshop participants.

While present trends and policy agreements such as the SDGs are governing country-level commitments for development during 2015-2030, forward-looking 
alternative pathways can assist in guiding policy for the decades from 2030 to 2050 that will ideally orient the HKH toward prosperity in 2080.

What will the prosperous scenario for the HKH look like, and what pathways lead to it? These questions were at the centre of a participatory scenario-development process that was facilitated by this chapter team. Through this process, participants identified challenges and opportunities, and created the storylines which are described here. Working backward from the three 2080 scenarios - and with reference to currently available national commitments to the Sustainable Development Goals (SDG) and its targets for 2020 and 2030 - the participants identified two broad potential pathways to prosperity and the necessary actions that can put the HKH on one of those pathways (see Fig. 4.1).

Participants in this visioning process developed three storylines, one for each possible future scenario in the region. In the worst or downhill storyline, regional conflicts over resource sharing persist - and even multiply as scarcity increases. People and institutions do not benefit from emerging opportunities for efficient resource use. Communities remain isolated from the larger market systems. Mountain livelihoods do not include inclusive growth through new innovations, skills and practices. Ecosystems are degraded and biodiversity loss continues, mitigation efforts fail, and fossil fuels remain the dominant energy source. Climate change impacts reflect the Intergovernmental Panel on Climate Change (IPCC)'s worst case scenario - global temperature rising by substantially more than $2.0^{\circ} \mathrm{C}$. In short, the downhill scenario encompasses strong climate change, a socially, economically and politically unstable region, and strong ecosystem degradation.

In the business as usual storyline, today's economic growth patterns persist. Business and industries strive to keep meeting economic targets, while most meet only the minimum required standards for the environment and sustainability. There is some cooperation among HKH countries, although the cooperation is neither envisioned nor realized in all the ways in which it could succeed, nor in all the sectors where it could do so. The value of ecosystems is recognized by some, but not as broadly or in as many quarters as possible. Although some climate change mitigation efforts are put in place, they do not proceed rapidly or effectively enough to meet the $1.5^{\circ} \mathrm{C}$ target set at the UNFCCC Conference of Parties 21 (COP21), held in Paris in December 2015. In short the business as usual scenario envisions strong climate change, medium social, economic and political instability, and medium ecosystem degradation.

In the prosperous storyline, regional cooperation across sectors and across governing institutions enables mountain and downstream people to utilize a full range of ecosystem services, to reduce disaster risks and to enjoy sustainable livelihoods and economic growth. The diversity and uniqueness of the region's natural resource assets, political life, and collaborative capacities are embraced. Biodiversity flourishes and the health of ecosystems improves. Climate change mitigation efforts largely succeed, as the regional economy shifts to clean and renewable sources for most of its energy needs. The impact of climate change reflects the IPCC's moderate scenario. So in brief the prosperous scenario represents $\mathrm{HKH}$ facing weak climate change, a socially, economically and politically stable region, and low ecosystem degradation.

The approach in Fig. 4.2 shows the three steps for deriving alternative pathways, using the $2080 \mathrm{HKH}$ scenarios (Step 1), the existing commitments towards 2030 (Step 2) and the alternative pathways (Step 3). This approach leads to a description of the actions necessary to achieve progress between 2030 and 2050, while keeping in mind the compatibility with the desired and undesired scenarios for 2080.

Participants in the consultative workshops acknowledged there are many possible and overlapping pathways toward the prosperous scenario but chose to consider two in great depth. These two pathways differ in the scale of actions, in the size of investment needs, in decisions about policy, in choices about technology, and in the inclusion of developmental actors.

Pathway to prosperity 1: Large-scale sustainable development investments with regional cooperation. The $\mathrm{HKH}$ looks to large or centralised projects in developing its natural resources. Water is harnessed for food and energy in ways that address gender inequality and persistent poverty. Human resources are mobilized on a large scale. National

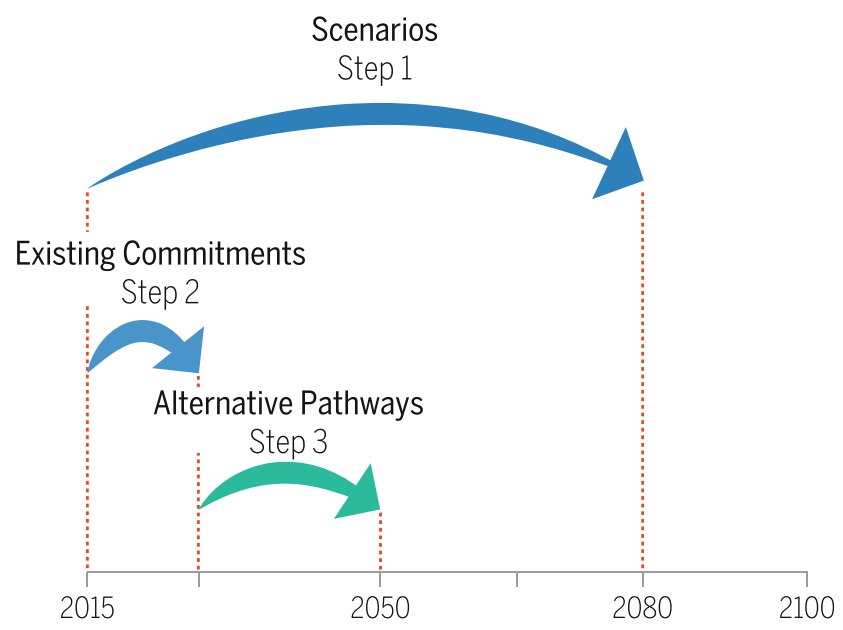

Fig. 4.2 Schematic representation of the steps followed in deriving Alternative Pathways towards 2050 
and international funding is provided through collaboration among state, corporate, and non-state actors. Countries increasingly share resources, improve communication, and acquire infrastructure for greater mobility. Institutions gain the strength to govern this cooperation within and outside the HKH. Examples of steps along this pathway today include:

- The South Asian Free Trade Area (SAFTA) (SAARC 2016)

- The Indus Water Treaty (Government of India 2016a)

- The India Bhutan Hydropower Treaty (Government of India 2016b).

Pathway to prosperity 2: Bottom-up investments with cooperation across multiple levels. Water and energy, while critical, are developed through smaller-scale and decentralized programmes that promote national self-reliance. Activity is coordinated among many non-state development and social actors, both nationally and sub-nationally. Multi-level governance structures are built to maintain local diversities; to fund projects, and to monitor progress toward scenario goals across actors. Examples of steps along this pathway are:

- Farmer-managed irrigation systems in Nepal;

- Local spring water management projects in Sikkim (Parvez 2017) and Uttarakhand, India, which include micro hydroelectricity projects supported by policy initiatives and entails upstream-downstream cooperation among villages for equitable and robust water allocation.

These two pathways toward a prosperous scenario for the $\mathrm{HKH}$ in 2080 are not mutually exclusive. Decision makers may combine actions from each pathway at various stages, as they weigh the benefits and risks and consider associated trade-offs. What is most certain is that for the HKH to seize its unique and emerging opportunities while meeting its challenges, time is of the essence. If actions through 2030 do not pick up speed, but remain at the levels now envisioned, the region will not build the cooperation and multilevel governance structures that are needed to develop its natural resources in ways conducive to prosperity.

\subsection{HKH Scenarios for 2080}

Making the HKH prosperous in the future is the target. But there are some important questions: What path needs to be followed to make the HKH region prosperous in a time-bound manner? What additional and new actions need to be adopted? What needs to be avoided? What actions decided now can keep the options for a prosperous HKH open in the years to come? To answer these questions, it is necessary to understand the possible pathways that can emerge due to ongoing (in reference period 2015) and likely future decision-making processes locally, nationally, regionally, and globally. This will help us understand how human wellbeing and ecosystem sustenance can continue in the HKH. In the face of uncertainty surrounding various drivers of development, such as technology, demography, socioeconomic decisions, governance systems, and resource availability, there can be no single answer to the above questions. But it is imperative to explore them because a range of plausible futures helps in the design of future agenda setting, course of action through uncertainty reduction, consensus building for strengthening cooperation, and identification of gaps between desired policy setting and current policy settings.

Currently, there are no HKH specific quantitative models for future scenarios (see Box 4.2 and Sect. 4.1.1 for Asia-specific scenarios reflected in global reports that have some relevance for the $\mathrm{HKH}$ ). In keeping with likely global futures, there are no comprehensive future scenarios in the literature covering environmental change, climate change, and social and economic development for the HKH region. However, there are standalone studies addressing climate change, economic development projections, and future outlooks which can provide limited guidelines to understanding the possible environmental and developmental scenarios for the region. This chapter brings together HKH-specific observed trends and expert knowledge (see Box 4.1 for the concepts and method we followed in this chapter) to develop qualitative scenarios and derive likely pathways.

As scenarios can be arranged in various ways, we restrict ourselves in this chapter to presenting future long-term 2080 scenarios (also see Box 4.1 and Fig. 4.1) for the HKH with in-depth development of three of the innumerable plausible futures. Here, 2080 is used as a key year to represent the 30-year period from 2070 to 2100 to assure independence from present policies and, by doing so, create more flexibility for non-linear changes and more space for creativity in identifying opportunities. Higher or lower degradation of the HKH's ecosystem resources, more or less political instability within the region, and good or poor progress in global negotiation outcomes in the context of climate change will have important implications for opportunities and challenges associated with climate-related vulnerability, human wellbeing, and sustainability within the region. Based on the consultative workshops of this scenario-development exercise and a review of the literature, ecosystem health, climate change, and weak governance leading to political unrest or local conflicts were considered the most important challenges for the HKH. Participants developed the storylines for three HKH 2080 scenarios based on the likely nature of these challenges. 
Most current action plans and projected pathways to prosperity emerging from existing policies and commitments end in 2030. To prepare pathways toward prosperity beyond 2030, it is useful to set clear goals for 2050 based on a prosperous future scenario. Based on consultative workshops, the "prosperous HKH" scenario was selected as best representing a desired sustainable future for the $\mathrm{HKH}$ (Fig. 4.1). Assessing available knowledge to determine how the goals for 2050 can be achieved will help decision makers to develop near- to medium-term decisions, policies, and actions with effective entry points and timelines. To ascertain long-term sustainability through potential pathways developed for 2050, this chapter uses the three scenarios of 2080 to enable the assessment of desired and undesirable development strategies and actions beyond 2030, while moving toward 2080 through 2050.

\subsubsection{Global Scenarios and Regional Outlooks}

Global likely futures for the Asian region are mentioned in reports by the OECD, FAO, and The World Bank, among others. Important regional and global outlooks include the United Nations Environment Program's (UNEP) Global Environmental Outlooks (GEO 1 to 5) (UNEP 1997, 1999, 2002, 2007, 2012), the Asian Development Bank's Asian Century and its Energy Outlook (ADB 2013, 2015), IPCC Regional Scenarios (Parry et al. 2007; IPCC 2013), and Global water futures (Gallopín 2012). While these are broad-based outlooks covering the economy and environment, there are sector-specific outlooks for energy, water, land, and forests. Most of these outlooks present a reasonably positive future falling between increased economic and environmental wellbeing, though the outlooks vary in their focus and proximity to economic or environmental wellbeing. For example, the outlook of GEO 3 and 4 are more proximate to economic wellbeing, while FAO Forests 2020 (FAO 2010) is more proximate to environmental wellbeing.

The Global Environmental Outlooks of UNEP are among the more prominent environmental outlooks available at the global scale which provide useful insights into the path the world may take during the period presented. Table 4.1 presents an assessment of how accurately one outlook is able to portray the possible future by comparing the outlook's projections with the actual trend. It is clear from Table 4.1 that GEO 1 was able to accurately project the calorie intake but not the food dependency for the Asia and Pacific region, which is a broader target than the calorie intake per person. In addition, the outlook also deviated from the actual trend in the expansion of agricultural area and life expectancy. Several factors may have contributed to these gaps, which need to be addressed in building possible scenarios, which include shifts in policy and socioeconomic trends due to improved human standards over the years in the areas of education, empowerment, and inclusion. It is worth noting that the extensive stakeholder consultation-based scenario building process used in this HIMAP report is more comprehensive, as a qualitative storyline-building exercise can handle multiple goals and priorities. Use of scale for scoring (Sect. 4.1 and Fig. 4.3), the relative distance from target for any goal based on stakeholder perception and experience also provides scope for defining a range rather than an exact value.

However, some of the major conclusions from the global assessment reports on possible future outlooks remain relevant for the HKH (e.g., desirable directions of change in fuel mix and the technology mix for power generation in the future). For the HKH, the results from the Global Energy

Table 4.1 Checking the reality with scenarios: How well did the GEO 1 scenario (UNEP 1997) represent the future?

\begin{tabular}{|c|c|c|c|}
\hline Projected scenario (2015-2050) & Observed trend & Proposed factors & Actual factors ${ }^{\mathrm{a}}$ \\
\hline $\begin{array}{l}\text { Calorie intake to reach up to } \\
2600 \mathrm{kcal} \text { per day per capita } \\
\text { and animal protein share to } \\
13 \% \text { of calories }\end{array}$ & $\begin{array}{l}\text { Calorie intake reached } \\
2665 \text { kcal per day per capita in } \\
2009 \text { (Asian Development } \\
\text { Bank 2013) }\end{array}$ & Increase in food supply & $\begin{array}{l}\text { Increase in food supply and } \\
\text { economic wellbeing }\end{array}$ \\
\hline $\begin{array}{l}\text { Increasing dependence on food } \\
\text { imports globally and in Asia } \\
\text { Pacific }\end{array}$ & $\begin{array}{l}\text { The Asia and Pacific region is a } \\
\text { net exporter with a balance } \\
\text { standing at } 4 \% \text { of the total } \\
\text { merchandise by value in } 2014 \\
\text { (The World Bank 2014) }\end{array}$ & $\begin{array}{l}\text { Land degradation and } \\
\text { insufficient access to } \\
\text { technologies }\end{array}$ & $\begin{array}{l}\text { Increased production coupled } \\
\text { with trade restrictions }\end{array}$ \\
\hline $\begin{array}{l}\text { Share of agricultural land to } \\
\text { increase to } 15 \% \text { of global land } \\
\text { area from a baseline year of } \\
1990\end{array}$ & $\begin{array}{l}\text { Agriculture land area declined } \\
\text { slightly to } 12.6 \% \text { of global land } \\
\text { area from } 1993 \text { (FAOSTAT } \\
\text { 2012) }\end{array}$ & $\begin{array}{l}\text { Increasing food demand, } \\
\text { deforestation }\end{array}$ & $\begin{array}{l}\text { Competition for land from other } \\
\text { economic sectors }\end{array}$ \\
\hline $\begin{array}{l}\text { Life expectancy to increase to } \\
55 \text { years (India) }\end{array}$ & $\begin{array}{l}\text { The life expectancy was } \\
66 \text { years in } 2013 \text { (The World } \\
\text { Bank 2013) }\end{array}$ & $\begin{array}{l}\text { Improvement in individual } \\
\text { health, nutrition and reduction } \\
\text { in poverty }\end{array}$ & $\begin{array}{l}\text { Better than expected } \\
\text { improvements in health, } \\
\text { nutrition and poverty reduction }\end{array}$ \\
\hline
\end{tabular}

a'Based on authors' observations 
Fig. 4.3 Breakdown of workshop participants' affiliation and subject expertise $(G O V$ Government offices, $R S$ Research Scientists, $N G O$

Non-Government Organization, $F S$ Food Security, WR Water Resources, EC Ecosystems, $L H$ Livelihoods, IT Information and Technology)
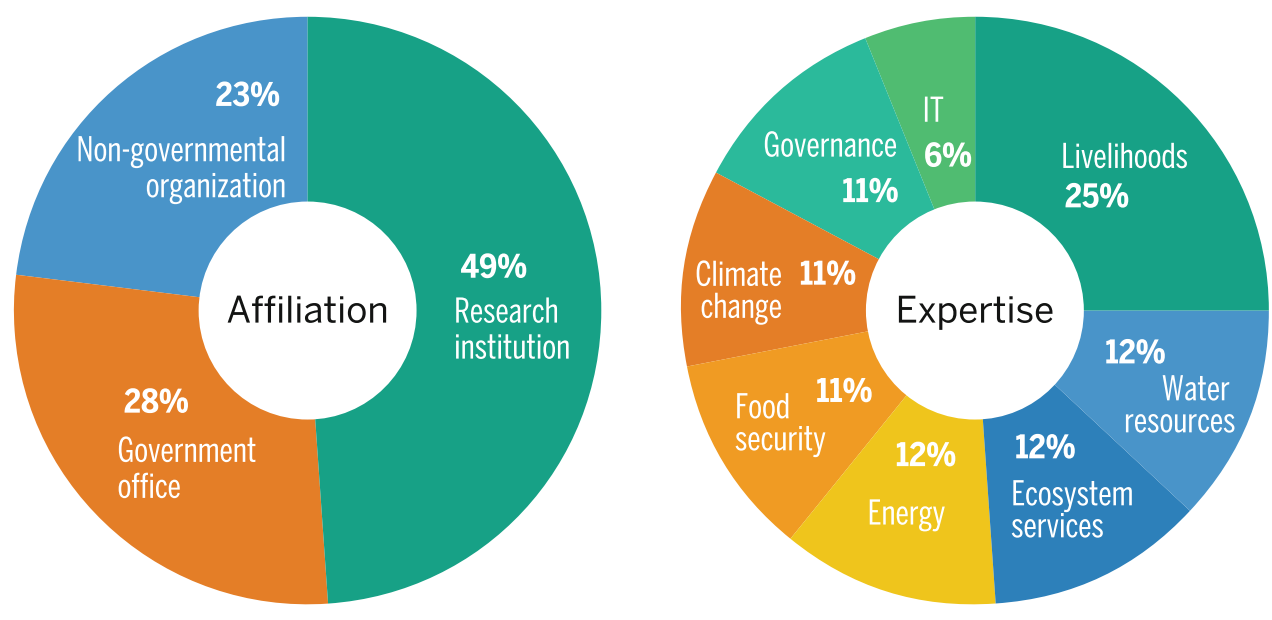

Assessment (Johansson et al. 2012) also remain relevant. In 2015, SDG's major goals, targets, and indicators are specified and implementation mechanisms and pathways are left to be decided by local decision makers. Goal 13 of the SDGs requires urgent action to combat climate change and its impacts. So, IPCC and GEA transformation pathways become relevant.

Equally relevant for the HKH are global SDG indicators: these emphasise the need for disaster risk reduction (DRR); the inclusion of women, youth, and local marginalized groups; the need to protect, restore, and promote a sustainable terrestrial ecosystem; sustainable forest management; avoiding desertification; reversal of land degradation; halting biodiversity loss; and meeting water and sanitation needs by the specific monitoring of green cover indices of mountain ecosystems and changes in the water-related ecosystem.

In keeping with likely global future scenarios, there are no comprehensive future scenarios in the literature covering environmental change, climate change, and social and economic development specifically for the HKH. However, there are studies addressing climate change, economic development projections, and outlooks that can provide, though in a limited sense, guidelines for understanding the possible environmental and developmental scenarios for the region.

Natural Resources: The FAO-OECD indicates a positive outlook for agriculture for countries in the HKH, showing an increase in production of rice and wheat until 2025 (OECD/FAO 2016). These outlooks have limitations since all of them cover the Asia and Pacific region as a whole and do not provide $\mathrm{HKH}$-specific information.

Social: The projections available indicate continued population growth in the HKH countries with rapid projected growth in Afghanistan, followed by Pakistan and India. The region is projected to experience a rapid urbanization in Nepal, followed by Afghanistan and India (The World Bank 2016).
Economic: The sources in the literature, which mostly focusses on the short term, do not agree on the extent of growth in the region. The outlook by ADB indicates positive growth, while that of the International Monetary Fund (IMF) indicates deceleration in the short run (International Monetary Fund 2016; Asian Development Bank 2016). The outlook drawn for Southeast Asia, India, and China projects that the region will experience mild to moderate economic growth during 2016-2020 (OECD 2016). The Global Energy Outlook (OECD/IEA 2016) projects that South Asia will not be able to achieve full energy access targets by 2030 in a no-policy support scenario and will only be able to achieve rural energy access goals with substantial fuel price support policies such as subsidies (Pachauri et al. 2012).

Since these are sector-specific outlooks, it is unclear from the literature how the climate and economic outlooks for the region would interact with other sectors in the future, hence it is difficult to draw an overall picture for the HKH. However, it is possible to build a composite outlook based on a combination of individual economic, environmental, and climate change outlooks available for the region. To overcome the lack of an integrated regional vision on the future of the $\mathrm{HKH}$, a HKH-specific participatory visioning exercise was conducted as part of the current HIMAP assessment (see Box 4.1).

\subsubsection{Challenges and Opportunities for the HKH}

To build the storyline and pathways for the HKH scenarios, the main drivers in the region were determined on the basis of reviews (see other chapters in this assessment report) and through intensive consultative workshops conducted sequentially from January to August 2016. Participants in these workshops were scientists, decision makers, development practitioners, HIMAP Steering Committee Members, and Chapter Lead Authors from all HIMAP chapters. 
Fig. 4.4 (a) Challenges and (b) opportunities as identified by the workshop participants, expressed as a percentage of the 237 responses
(A) Challenges

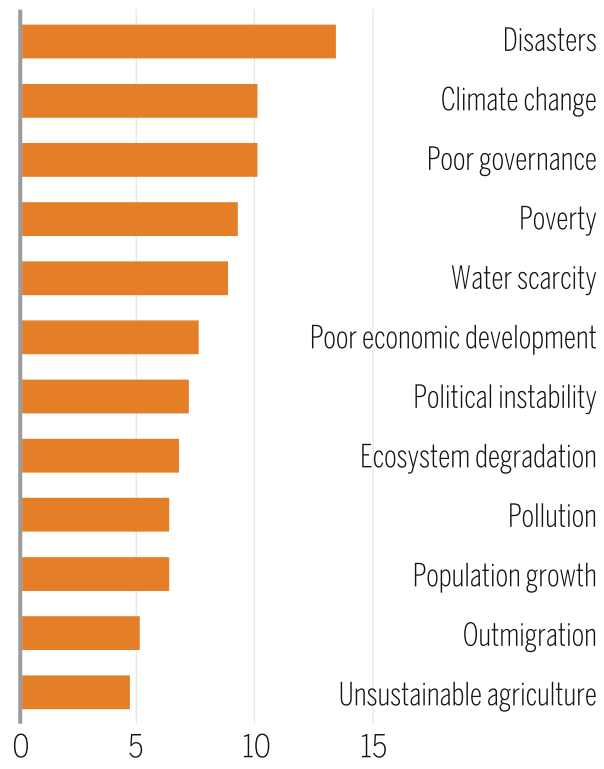

(B) Opportunities

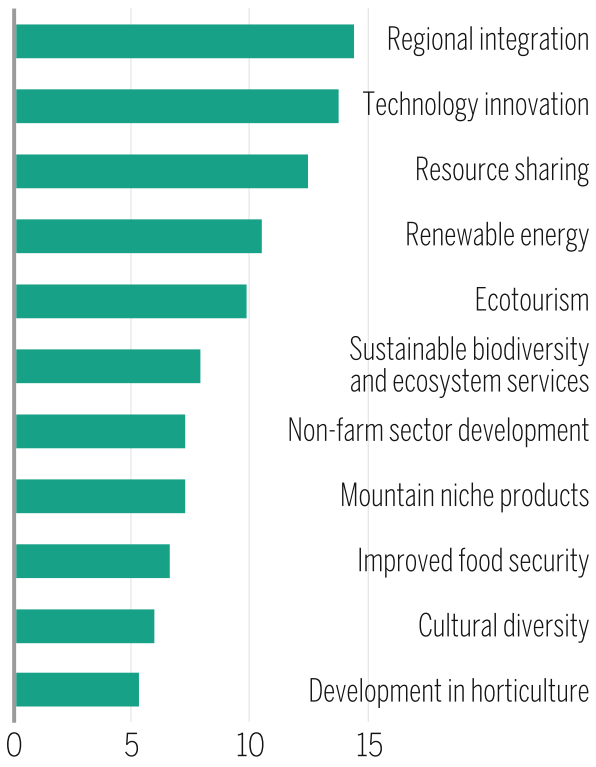

Percentage of responses

$(n=237)$

Science experts participated in four workshops and decision makers from government and non-government organizations participated in two different workshops. Participants included representatives of all eight HKH countries and professionals working on the region from the rest of the world. Figure 4.3 provides a breakdown of the affiliations and subject expertise of the participants from all the consultative workshops. A total of 139 people from 74 different institutions participated: $49 \%$ from research institutions, $28 \%$ from government offices, and $23 \%$ from NGOs. The participants represented eight broad fields of expertise: $25 \%$ were working in livelihoods; $12 \%$ in ecosystems, energy, or water resources; $11 \%$ in governance, forest, or climate change; and $6 \%$ in information technology.

During these workshops, the starting point was identification of the challenges for the region. Each time the objective was to enrich the results of the previous workshops using the output from those workshops. The science groups, facilitated by the chapter team, categorized the identified challenges and opportunities into the three scenarios. After discussing the challenges and opportunities for the HKH, the scenarios were presented and discussed in all workshops. In the workshop attended by the decision makers, participants were also asked to give their views on actions to attain the desired future and actions to prevent developments that might lead to an undesired future. Figure 4.3 gives an overview of the stakeholders involved in the workshops.

The participants from all workshops provided 237 responses addressing challenges and opportunities for the
HKH. Based on a prioritization exercise in post-workshop analysis, this chapter team clustered the challenges and opportunities as presented below in Fig. $4.4 \mathrm{a}$, b. The participants' prioritization of the challenges identifies disasters as the most significant challenge in the region (15\%), followed by climate change and poor governance (11\%), poverty $(9 \%)$, and water scarcity (8\%) (see Fig. $4.4 a$ ). In terms of opportunities, the participants considered the most important to be regional collaboration/integration (14\%), technology innovation $(13 \%)$, resource sharing (12\%), and renewable energy (11\%) (see Fig. 4.4b). For storyline development, the chapter team clustered these challenges and opportunities under five major themes: climate, natural resources, governance, social, and economy.

\subsubsection{Storyline for HKH Scenario: "Downhill"}

Compared to the 2015 baseline, the HKH will not be able to prosper by 2080 due to lost opportunities and multiple challenges that will increase over time. Owing to climate change, increasing political unrest, and strong ecosystem degradation, the socioeconomic condition of people in the HKH will deteriorate. Participants' perception of their status and expected change in any component under any theme are expressed by scores on a 1-5 scale (where $1=$ poor, $5=$ very good) for the "downhill" scenario for 2080. These are presented in Fig. 4.5. Details of the storyline for this scenario are given below. 
Climate: Strong climate change will increase extreme events such as flooding, droughts, glacier melting, and river flow, resulting in water scarcity when it is needed and too much water at other times. There will be high vulnerability to climate-induced factors and less adaptation capability.

Natural Resources: Strong ecosystem degradation will threaten biodiversity and the development of improved crop systems for arresting biodiversity loss. Ecological and social resilience will decline and unplanned urbanization will increase, resulting in a loss of biodiversity. Resource use will intensify as a result of migration and tourism.

Governance: More political unrest in the region will result in conflicts over natural resources (e.g., water) and there will be little funding available/allocated for adaptation capacity. Institutional, political, and overall governance systems will be weakened and unable to function well at local, national, and regional levels and will fall short of global expectations. This will undermine the regional integration and cooperation in managing natural resources, leading to further conflict and mismanagement of the resources; the trust in multilateral organizations will be weakened, resulting in a poor response to regional issues with global significance.

Social: More national, regional, and global inequality will lead to serious food and nutrition insecurity, social tensions, and a high rate of migration (rural to urban and highland to lowland). Water scarcity for drinking and irrigation will drive people to migrate, with the poor left behind, leading to high mortality and suicide rates, high population density, and more urbanization. As a result, there will be a high fertility rate, high child mortality, huge refugee camps, and increasing inequalities, as well as a loss of traditional values, norms, and local knowledge.

Economy (including infrastructure and energy): High resource use intensity in production and consumption processes, a lack of innovation and efficient production processes, fossil fuel dependency, rural energy crises, and vulnerability will lead to a decline in economic progress. Competition for meagre resources and poor livelihoods will increase conflict and reduce motivation for innovation and cleaner, renewable energy. Communication will improve and competition will be high, leading to huge gaps in demand and supply.

\subsubsection{Storyline for HKH Scenario: "Business as Usual"}

Present economic growth patterns persist. Business continues as usual without sufficient change to meet existing and expected challenges to economic growth, and without opening an alternative pathway toward a prosperous HKH. The region has been able to achieve cooperation in some sectors with potential for more. Ecosystems values are slowly being recognized. Mitigation efforts are in place but are not sufficient to meet the $1.5{ }^{\circ} \mathrm{C}$ target set at COP21.

The changes that participants perceive will take place in the different thematic domains for each of the components by 2080 , as compared to the 2015 baseline, are expressed using scores on a 1-5 scale and are presented in Fig. 4.5. Details of the storyline for this "business as usual" scenario are given below.

Climate: The region will experience moderate to strong climate change with temperatures rising beyond the Paris Agreement 2015, as well as more rainfall and extreme weather events. It will also lead to rapidly diminishing glaciers and moderate to severe ecosystem changes.

Natural Resources: Ecosystem health will experience an unstable equilibrium; there will be larger challenges in containing environmental degradation, promoting biodiversity conservation, and ensuring upstream and downstream linkages.

Governance: Implementing NDCs and achieving SDGs and overall growth remains a challenge because of conflicts of interest and inadequate cooperation in the region, as well as difficulties faced by international/global institutions. With scientific evidence playing a greater role in policy processes and the prospect of key alliances being formed for resource sharing, the possibility of addressing challenges will emerge to a certain extent.

Social: Despite SDGs being in place, livelihoods will still suffer from disparities, including food insecurity and associated malnutrition. Increasing floods and limited success in reducing vulnerability and adaptation to climate change will continue to make life more difficult. More people will start living in cities. Availability of funds following from the Paris Agreement 2015 will offer opportunities for technology transfer and improve food security.

Economy (including infrastructure and energy): The focus on mountain niche product development and adoption of ICT and remote sensing technology will increase. There may be massive infrastructure development that is not in sync with "green" approaches in some parts of the HKH. Even the green development taking place is not sensitive to the gender dimension, at times leading to slower economic progress. More alternative energy development (water + wind + solar) with benefit-sharing mechanisms will evolve, leading to fewer power cuts and enhancing access to power.

\subsubsection{Storyline for HKH Scenario: "Prosperous HKH"}

Regionally and across sectors, cooperative efforts will allow mountain people to prosper through sustainable livelihoods 
Fig. 4.5 Comparative scores for various components of the thematic areas in different scenarios. Note Each numerical value is an outcome of the consultative workshops. In the diagram, each value shows the average of all the scores allocated by participants on a $1-5$ scale (where 1 represents "poor" and 5 represents "very good") for a particular component (please see the legends where applicable). While scoring, the initial score was given to the baseline 2015 status of each component and then changes are reflected in 2080 scenario scores, which vary by scenario category
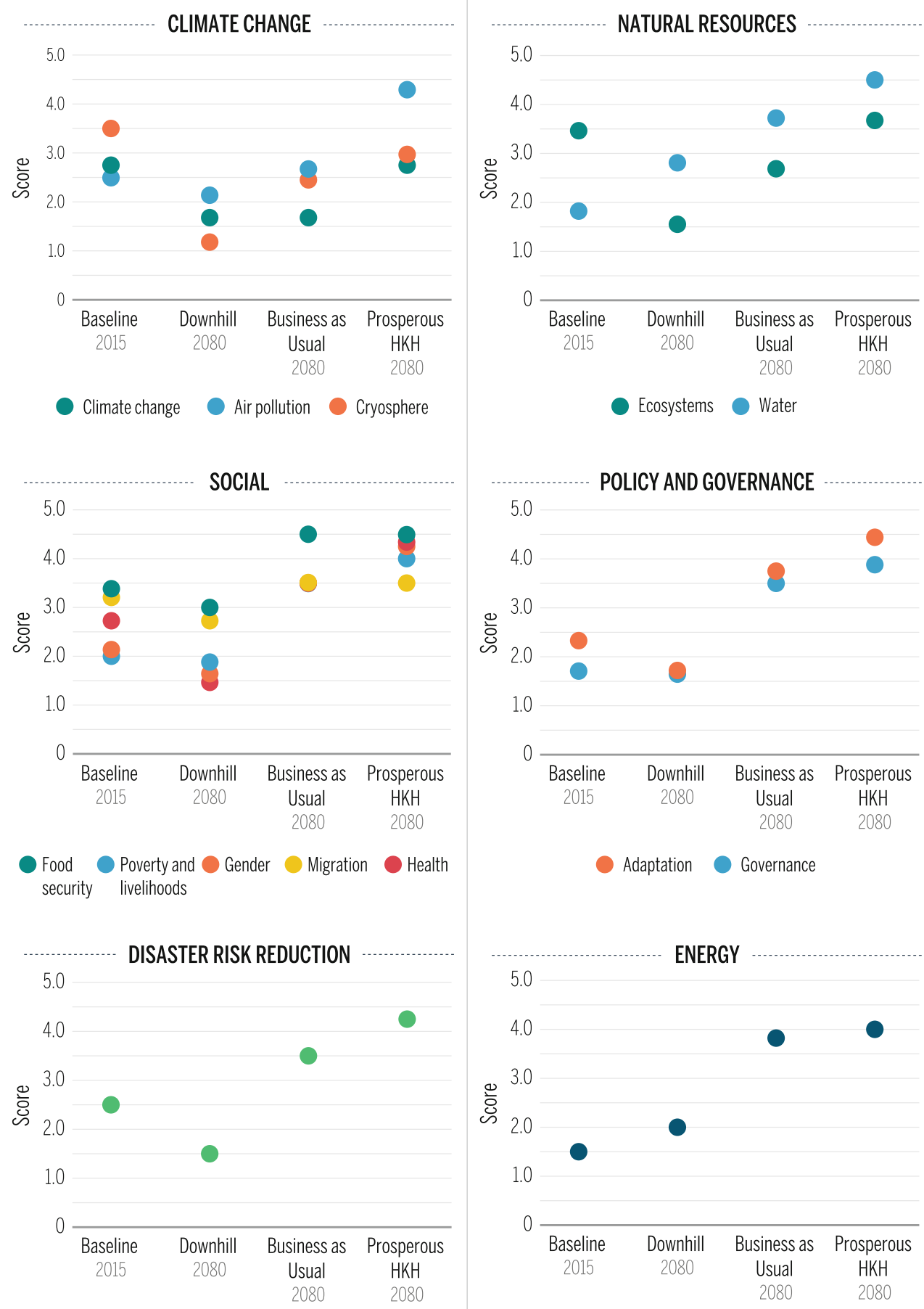

and economic growth. These efforts will embrace the diversity and uniqueness of the region's natural resources, its political life, and its capacities for collaboration. Biodiversity and ecosystems values will improve. Global mitigation efforts will have largely succeeded, and clean and renewable energy sources will dominate the energy supply. Climate change will follow a moderate IPCC scenario. Participants used scores on a 1-5 scale to rank the changes that they expect to take place in the different thematic domains in
2080 compared to the 2015 baseline, which are presented in Fig. 4.5. Details of the storyline for this "prosperous HKH" scenario are given below.

Climate: Since climate change is a global phenomenon, climate in the HKH may not completely stabilize by 2080, as stabilization of climate change and its impacts may follow several years after GHG emissions are reduced, going by IPCC assessments. However, it is expected that the $\mathrm{HKH}$ 
will have mainstreamed climate change mitigation and adaptation to the fullest extent possible and that decisions will be made based on risk assessments. There will be a widespread global understanding of the urgency and means of addressing climate change.

Natural Resources: Reduced poverty will have synergies with the region's biodiversity and ecosystems, with the region enjoying healthy ecosystems. Conservation principles are well integrated into policy and individual decision making, leading to better conservation of natural resources. With reduced pressure on the land, land degradation will be diminished and the improved soil productivity will benefit the region's agricultural production.

Governance: Governance systems in the region will evolve and political unrest will be replaced by stability that will usher in regional cooperation, leading to acceptable and amicable solutions to the issues in the region. As a result, regional institutions will become strong, with necessary resources for providing better governance. Migration will continue but under ideal circumstances of regional cooperation and favourable labour laws. Governments and the private sector will collaborate, leading to better development and implementation of policy solutions, and overall efficiency and effectiveness. Regional cooperation initiatives such as SAARC and intercontinental initiatives like BRICS would have been strengthened, playing a pivotal role in addressing transboundary issues such as air and water pollution and trade of resources such as energy, regionally harmonized food standards, and enhanced regional transportation, communication, and information exchange facilities.

Social: As a result of reduced climatic impacts and better governance for vulnerability reduction, the mountain region will experience a significant reduction in poverty. At the same time, the region will experience sustained cultural diversity. Population growth will stabilize and people will have $100 \%$ access to education, while a substantial reduction in inequality, along with enhanced social equity and empowerment of women, will lead to an equitable society. As a result, societies will show high aspirations for continued improvement and for a high standard of living.

Economy (including infrastructure and energy): The region will move toward a low carbon economy with significant decoupling of economic growth from fossil fuel use. Energy use efficiency will become one of the major criteria for production and consumption of products and services in all sectors. The behavioural attitude, to offset the technical efficiency gain through an absolute energy demand increase, will not undermine the full benefits of energy efficiency improvements, due to a better mix of policy interventions (including fiscal instruments), higher levels of economic prosperity, and no unmet demand for energy (Roy 2000 ; Sorrell et al. 2009). Scientific advancement will lead to rapid technology development in the areas of health, energy, information technology, food and agriculture, natural resource conservation, financial inclusion through tele-banking, etc. With free trade, there will be an impetus for local economies to become vibrant and integrated. Better regional cooperation will lead to the implementation of strategies such as a regional electrical grid and regional transportation corridors.

The comparative evaluation of the scenarios is done based on quantitative scores given by participants. Scores on a 1-5 scale (where 1 is the lowest and 5 is the highest) were given by participants based on their individual assessments of the baseline status of each component under different thematic areas. For example, the climate theme represents three components: climate change, air pollution, and cryosphere. Participants, based on their knowledge, used a 1-5 scale to score the 2015 (baseline) status of the components and, based on their own storylines, scored the same component across various scenarios. This is summarized in Fig. 4.5. The economy thematic area is represented by one component, energy, because participants identified energy as a major driver of the economic wellbeing of the HKH.

\subsection{HKH Baseline in 2015}

After the first step of envisioning long-term future challenges and opportunities, the second step of "Back casting" (Fig. 4.2) information on the baseline 2015 status of the different indicators was collected from the other chapters to determine the existing historic trends. In addition, the policies presently in place are analyzed to extract possible barriers and bridges for the challenges identified in the $\mathrm{HKH}$ 2080 scenarios. The 2080 scenarios defined by storylines will need to be achieved starting from the baseline of 2015 . At present, the $\mathrm{HKH}$ is undergoing rapid demographic, economic, social, and political changes, hence any quantitative scenario based on past trends will need to be viewed with caution. However, this chapter builds scenarios following the qualitative process and scoring, which gives enough flexibility that visions and imaginations about future possible transformations can be built into the storylines. This chapter focuses on HKH-specific scenarios, which cannot be done in an isolated way. Global and larger regional developments will influence the future of the HKH region. The likely global emissions future is represented mainly by the Representative Concentration Pathways (RCPs) and Shared Socio-Economic Pathways (SSPs) (see Box 4.2). A summary of 2015 baselines for each country in the HKH (in the case of India, Pakistan, Afghanistan, Myanmar, Bangladesh, and China, this is not exclusively HKH-specific, as these countries fall both in the HKH and non-HKH regions) is 
prepared based on the synthesis of different chapters in this assessment report, vision documents, and SDG documents of the countries. Defining the baseline helps in understanding the challenges of each country in the region to attain HKH-wide prosperity. In the absence of HKH-specific information for many large countries, the countrywide baseline status is summarized in Sect. 4.2.1.

Box 4.2 How are global climate change emissions scenarios and shared socio-economic pathways related?

For more than a decade, the dominant climate change-related scenarios were based on the IPCC Special Report on Emission Scenarios (Nakicenovic and Swart 2000). These scenarios were developed through a process that involved:

- A literature review;

- Generation of qualitative storylines based on the outcome of the literature review and further interactions; and

- Development of quantitative scenarios using the qualitative storylines.

The SRES scenarios have been highly influential in climate change research and policy, but several years ago a process was initiated to develop a new scenario framework that is more comprehensive and builds on a set of global and regional scenarios (Nakicenovic et al. 2014). The logic of the scenarios has been distinctly changed and now no longer uses emission scenarios but defines the future along several lines and pathways.

Representative Concentration Pathways (RCPs) define the emission pathways (Moss et al. 2010). On the other hand, Shared Socio-Economic Pathways (SSPs) describe plausible alternative trends in the evolution of social, economic, political, and natural systems over the 21st century, globally and for major world regions. SSPs comprise two elements, narrative storylines and quantified measures of development (O’Neill et al. 2014). SSPs themselves do not include outcomes in terms of emissions or impacts; rather, they quantify factors considered to drive the outcomes, such as population or economic growth. Quantification of the consequences is done by scenarios produced based on SSPs. As a minimum, SSPs include assumptions on future demographics, economic development, and the degree of global integration.

\subsubsection{National Considerations}

Afghanistan: Afghanistan tops the list of eight countries of the HKH in poverty measured by head count ratio. Government policies and budget spending on poverty can be seen as major barriers. In 2015 as regards MDG goals on net enrolment ratio significant improvement was documented while health had modest improvements. Carbon dioxide emissions increased. Food security, water, sanitation, and energy-related goals show marginal progress. The National Priority Programs and Aid Management Policy (AMP) had been targeting improvement aid effectiveness, cooperation, accountability development (Islamic Republic of Afghanistan 2012).

Bangladesh: Substantial decline in head count poverty ratio from $60 \%$ during 1990 to $29 \%$ by 2015 was recorded. With annual population growth at $1.32 \%$ and significant progress in water and energy sectors major challenges are identified in malnutrition and food security, disaster vulnerability. Girl child education in rural areas, improvement in rural income, agriculture production, awareness building are identified as means to address the challenges in reducing malnutrition. Scientific assessment, policy interface, institutional and human capacity building for public sector are seen as enabler to accelerate key developmental projects (Peoples' Republic of Bangladesh 2012).

Bhutan: The SAARC Development Goals, Bhutan's country report (Royal Government of Bhutan 2013) mentions progress in poverty, inequality (especially women and children) and hunger reduction, infrastructure development. The percentage of people living below poverty is $11.2 \%$ in 2012 , Stunting and malnutrition of children under five years reduced by $6.5 \%$ and $4.3 \%$ respectively during 1999-2010. The rural houses electrified improved from 54 to $87 \%$ during the period 2012-2017. The country has achieved $100 \%$ telephone connectivity. The rising unemployment and mountainous landlocked economy are the critical challenges. China: The poverty head count ratio of China reduced from $66.6 \%$ to $6.5 \%$ during the period 1990-2012 (World Bank 2012). The maternal mortality rate reported at 20.1 per 100,000 births in 2015 compares with 88.8 per 100,000 in 1990. The forest cover and forest reserves increased by 32.78 million hectares and 2.681 billion cubic meters respectively during the 2005-2015. Increase in share of non-fossil fuels by $11.2 \%$ per GDP unit and reduction in carbon dioxide emission per GDP unit by $33.8 \%$ was reported in 2014 . Greater interconnectivity and interdependence has strengthened China as a community of shared destiny. China has the highest per capita $\mathrm{CO}_{2}$ emissions among $\mathrm{HKH}$ countries. Need for further adoption of green technologies is identified as a big challenge (The People's Republic of China 2016). 
India: Eradication of extreme poverty in India still continues due to its complex relations with various social, economic and environmental components. Improvements in net enrolment ratio had led to enhanced focus on higher education. The eradication of hunger and control of malnutrition continue be a daunting task due to low level of progress so far. Food security is seen as outcome of landuse change triggered by urbanisation process, infrastructure development and inconsistencies in monsoon pattern. Anaemia is prevalent among $50 \%$ of women in the age group 15 to 49 and more than one third of are reported with low body mass index. Rank in Global Gender Gap Index is at 114 out of 142 countries. Gender equality at the workplace is also far off the track (World Economic Forum 2014). Access to safe drinking water continue to be a huge challenge (Government of India 2015a). Myanmar: Economic stagnation, which is an outcome of more than three decade long economic sanctions, fall in foreign investment, poor macroeconomic management, public-sector debt. Introduction of reforms in 2011 onwards helped the process of recovery (ADB 2014). During 20002012, social indicators such as reduction in population below poverty line, infant mortality rate, and population with access to safe water and sanitation improved (Table 4.2). Per capita carbon dioxide emissions increased from 0.1 to 0.2 tons. Structurally agriculture dominates with $31 \%$ of GDP and $50 \%$ of employment with a very low per capita income. Opportunities are from the strategic location, abundance of natural resources, tourism potential and youthful workforce. Emphasis is on growth-oriented support for agriculture and natural resources followed by actions on manufacturing for domestic and export markets.

Nepal: Extreme poverty is declining, with a large change from $42 \%$ in 1995 to $23.8 \%$ in 2015 however, with large degree of spatial variability across the country by gender and social groups. The adult female literacy rate tripled from 1990 to 2011. The proportion of population with access to basic water supplies and improved sanitation facility moved up from $46 \%$ in 1990 to $83.6 \%$ in 2014 and from 6\% in 1990 to $70.3 \%$ in 2014 respectively (Government of Nepal 2015).

Pakistan: Pakistan will become the fifth most populous nation in the world in 2050 growing at 2012-13 growth rate of $2 \%$ per annum. Twenty nine percent of the population lives below the poverty line, half of the population is unemployed, 77 out of 1,000 children die before their first birthday, and one in three does not have enough nutritional food. Slow growth, limited technological innovation, low agriculture inputs, and little government investment in the agriculture sector make the situation worse. Despite significant efforts energy shortages have impacted the quality of livelihoods, as well as business and agriculture. The exogenous developments such as climate change, reduced aid flows, stagnated import demands from developed countries are effecting the growth (Government of Pakistan 2013).

\subsection{Tracking Trends and Commitments for 2030: SDG's and NDC's in the HKH}

In the third step (Fig. 4.2), the existing trends and policies are extrapolated toward 2030. To achieve this, literature review and two main interactive processes are followed. One interactive process involved scientists engaged with other HIMAP chapters and a second with policy makers from the region. Section 4.2 provided a synthesis of historical trends mentioned in the different chapters of this volume and reflects the status of the 2015 baseline, while this section first summarizes the SDG targets (Sect. 4.3.1, Table 4.2) for various countries and not specific to $\mathrm{HKH}$, as they are available at country level only, and then continues to discuss thematic trends toward 2030 in Sect. 4.3.1. Possible directions toward 2030 are taken from different mandates of national governments reflected in national vision plans, SDGs, INDCs, and national communications. Table 4.2 shows that most of the countries have mentioned different targets and hence need financial requirements and implementation mechanisms, along with scientific strategies of mitigation and adaptation, to achieve the desired goals.

\subsubsection{Existing Sectoral Commitments Toward 2030 Sectoral/Thematic Considerations}

Based on the literature Table 4.3 explains the existing sectoral commitments of the countries towards policies and plans related to climate change. Compliance and implementation of (I)NDCs stands critical to address multiple SDGs especially to SDGs 13,14 , and 15.

The interaction with scientists engaged with other HIMAP chapters had as objective to elicit information using the following three major questions:

a. What are the main targets of your chapter theme? Mention the specific indicators behind the target.

b. What is the direction (on a quantitative scale of 1-5) of observed change in the indicator based on the past trends and using, for example, INDCs and SDGs relevant for the region and other policy documents or policy analysis documents? What is the likely direction of trends up to 2030 ?

c. Based on your answers to questions 1 and 2, what are the chances (on a quantitative scale of 1-5) that 2030 targets (e.g., $100 \%$ poverty reduction) will be achieved? What are the factors affecting the chances (e.g., weak policy enforcement, lack of resources, global climate change, conflicts with other sectors, reinforcing trends with other sectors, and so on)? 
Table 4.2 SDG targets of HKH countries

\begin{tabular}{|c|c|c|c|c|c|c|c|}
\hline \multirow[t]{2}{*}{ SDGs/Country } & $\begin{array}{l}1 \text { pour } \\
\text { firiviniti }\end{array}$ & 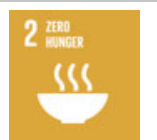 & 3 coosiciun & 4 buvir & 6 arcumatr & 6 ginumaing & 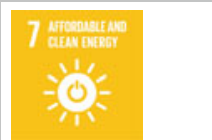 \\
\hline & $\begin{array}{l}\text { Target } 1.1 \\
\text { Poverty head } \\
\text { count ratio ( } \% \\
\text { population) }\end{array}$ & $\begin{array}{l}\text { Target } 2.2 \\
\text { Stunting } \\
(\%)\end{array}$ & $\begin{array}{l}\text { Target } 3.2 \\
\text { Infant } \\
\text { mortality }\end{array}$ & $\begin{array}{l}\text { Target } 4.1 \text { Gross } \\
\text { enrolment ratio }\end{array}$ & $\begin{array}{l}\text { Target } 6.1 \% \text { of } \\
\text { people with } \\
\text { improved water } \\
\text { access }\end{array}$ & $\begin{array}{l}\text { Target } 6.2 \% \text { of } \\
\text { people with } \\
\text { improved } \\
\text { sanitation access }\end{array}$ & $\begin{array}{l}\text { Target } 7.1 \% \text { of } \\
\text { population with } \\
\text { electricity access }\end{array}$ \\
\hline Afghanistan & $35.8(20)$ & $40.9^{1}(0)$ & $74(46)$ & $116(110)$ & $31(61.5)$ & $8(66)$ & $43(100)$ \\
\hline Bangladesh & $31.5(0)$ & $40(25)^{3}$ & 39 (NA) & $111.8^{4}(\mathrm{NA})$ & 86 (100) 2015 & $89(100) 2015$ & $59.6(100)$ \\
\hline Bhutan & 12 (NA) & 33.5 (NA) & 47 (NA) & 102.1 (NA) & 96 (NA) & 58.4 (NA) & 87 (NA) \\
\hline China & $6.5(0)^{5}$ & $9.4^{6}(7)$ & $12.2(6)$ & $103.9^{7}(90 \%) \mathrm{HSE}$ & $\begin{array}{l}\text { Improved } \\
\text { Efficiency }\end{array}$ & $\begin{array}{l}\text { Improved } \\
\text { Efficiency }\end{array}$ & 100 (NIL) \\
\hline India & $21.9^{8}(0)$ & $48^{9}(0)$ & $43.2(12.96)$ & $21.1(30) \mathrm{GEH}$ & $\begin{array}{l}16^{10}(90 \% \text { piped } \\
\text { water supply) }\end{array}$ & 38.81 (rural), (100) & $78.7(100)$ \\
\hline Myanmar & 25 (NA) & $28.6^{11}(\mathrm{NA})$ & 41.1 (NA) & $114.2(\mathrm{NA})$ & 84.1 (NA) & 77.3 (NA) & $52.4(100)$ \\
\hline Nepal & $23.8(0)$ & $40.5 \%(1)$ & $33(1)$ & 96.5 (99.5) NER & $\begin{array}{l}49.5(99 \% \text { piped } \\
\text { water) }\end{array}$ & $70.3(100 \%)$ & $76 \%(99 \%)$ \\
\hline \multirow[t]{10}{*}{ Pakistan } & $29.5^{8}(14)$ & $44(0)$ & $74(47)$ & $93.5^{7}(100 \%)$ & NA & $48 \%(90 \%)$ & $67(90 \%)$ \\
\hline & \multicolumn{6}{|l|}{ Legend } & \\
\hline & $\begin{array}{l}\text { Unbracketed } \\
\text { value }\end{array}$ & & & 2010-2013 & & & \\
\hline & Bracketed value & & $\begin{array}{l}\text { Afghanistan } \\
\text { values } \\
\text { indicate for } \\
2020\end{array}$ & $2025-2030$ & \multicolumn{2}{|c|}{ India sanitation value indicate for 2020} & \\
\hline & Infant mortality & & & \multicolumn{3}{|c|}{$\begin{array}{l}\text { No. of deaths of children less than one year of age per } 1000 \\
\text { live births }\end{array}$} & \\
\hline & \multicolumn{6}{|l|}{ Stunting \% } & \\
\hline & NER & & & $\begin{array}{l}\text { Net enrolment } \\
\text { ratio }\end{array}$ & & & \\
\hline & HSE & & & \multicolumn{2}{|c|}{ High school education } & & \\
\hline & GEH & & & \multicolumn{2}{|c|}{$\begin{array}{l}\text { Gross enrolment ratio in higher } \\
\text { education }\end{array}$} & & \\
\hline & NA & & & Not available & & & \\
\hline
\end{tabular}

\section{Sources}

Primarily table prepared based on following country reports and other sources if used are shown in superscript numbers

Islamic Republic of Afghanistan: Afghanistan Millennium Development Goals Report, 2012

Royal Government of Bhutan: SAARC Development Goals, Bhutan Country Report, 2013

Peoples' Republic of Bangladesh: Rio+20 Bangladesh National Sustainable Development, 2012

Peoples' Republic of China: China's National Plan on Implementation of the 2030 Agenda for Sustainable Development, 2016

Government of India: Achieving the Sustainable Development Goals in India A Study of Financial Requirements and Gaps, 2015

The Republic of the Union of Myanmar: Myanmar Unlocking the Potential, Country Diagnostic Study, ADB Report, 2014

Government of Nepal: Sustainable Development Goals 2016-2030 National (Preliminary) Report, 2015

Government of Pakistan: Pakistan 2025 One Nation One Vision, 2013

${ }^{1}$ Afghanistan Survey 2013. National nutrition survey of Afghanistan, Survey Report.

${ }^{2}$ World Bank Data 2013. https://data.worldbank.org/indicator/EG.ELC.ACCS.ZS

${ }^{3}$ ICAD 2018. Bangladesh: Country Profile on Nutrition and Child Stunting Trends.

${ }^{4}$ World Bank 2010. Trading Economics data. Gross er 111.8 https://tradingeconomics.com/bangladesh/school-enrollment-primary-percent-gross-wb-data. html

${ }^{5}$ World Bank 2012. http://povertydata.worldbank.org/poverty/country/CHN

${ }^{6}$ World Bank 2010. https://data.worldbank.org/indicator/SH.STA.STNT.ZS?locations=CN

${ }^{7}$ World Data Atlas 2013. https://knoema.com/atlas

${ }^{8}$ Asian Development Bank 2011. Poverty Data. https://www.adb.org/countries/main

${ }^{9}$ UNICEF Report 2013. https://in.reuters.com/article/health-nutrition-unicef/about-48-percent-of-children-in-india-are-stunted-unicef-idINDEE95607 N20130607

${ }^{10}$ Govt. of India Report 2017. https://www.hindustantimes.com/india-news/6-3-crore-indians-do-not-have-access-to-clean-drinking-water/story-dWIEyP 962FnM8Mturbc52N.html

${ }^{11}$ Frontier Myanamr 2017. https://frontiermyanmar.net/mm/node/4278 


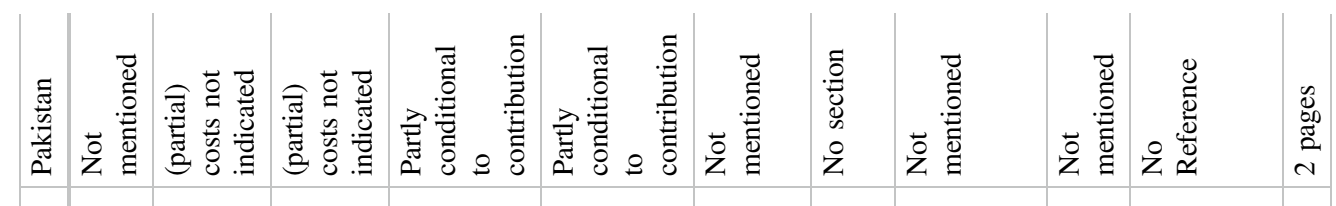

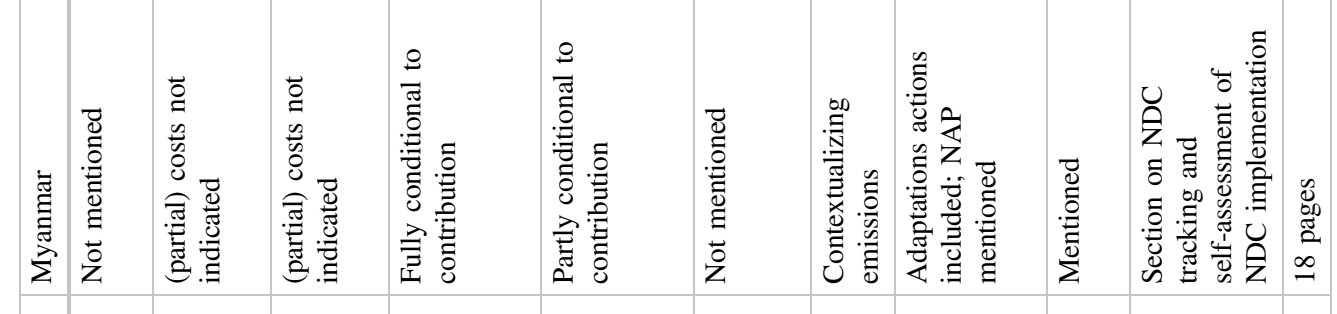

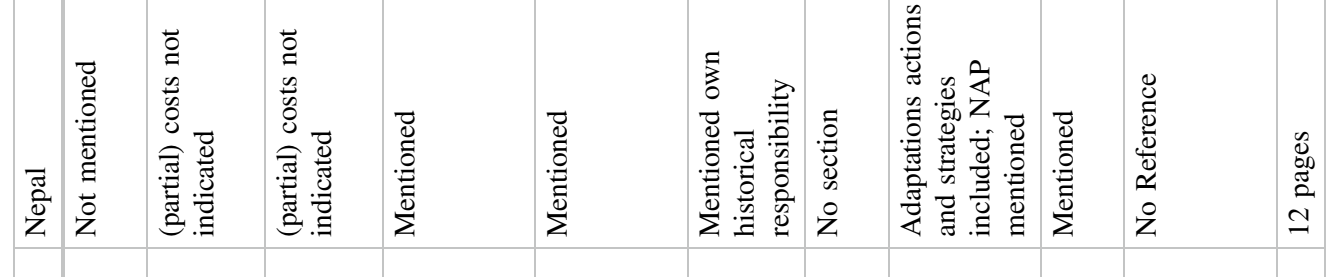

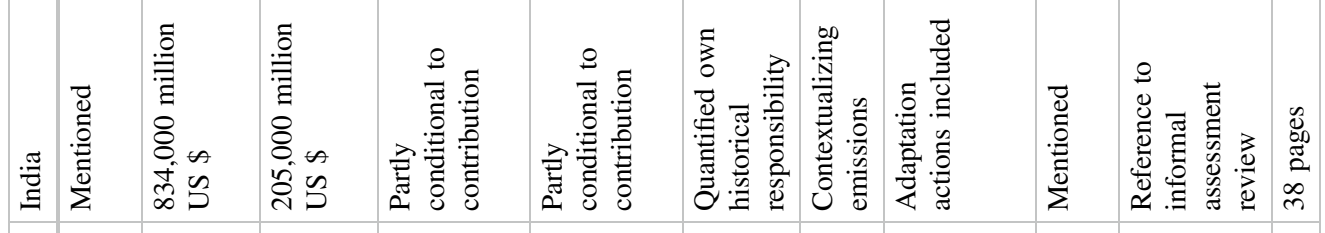

\begin{tabular}{|c|c|c|c|c|c|c|c|c|c|c|c|}
\hline 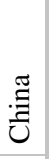 & 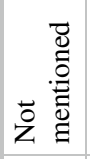 & 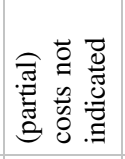 & 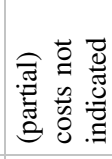 & 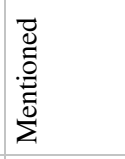 & 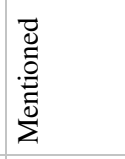 & 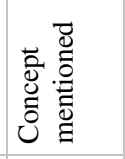 & 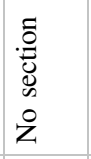 & 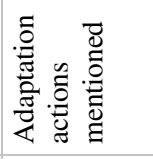 & 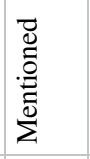 & 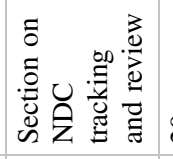 & 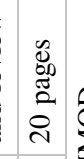 \\
\hline 胥 & 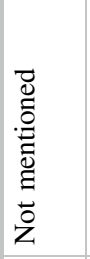 & 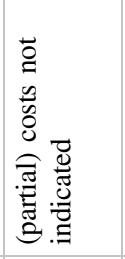 & 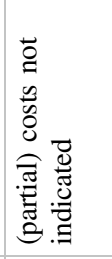 & 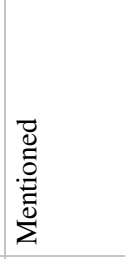 & 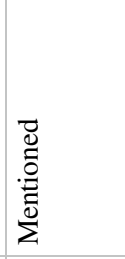 & 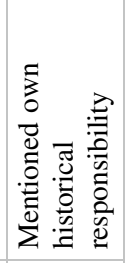 & 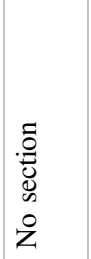 & 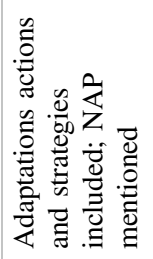 & 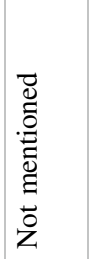 & 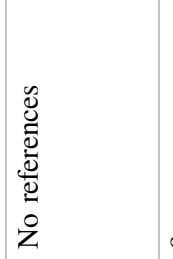 & 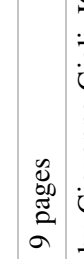 \\
\hline $\begin{array}{l}\frac{\pi}{0} \\
\frac{0}{0} \\
\frac{\sigma}{60} \\
\equiv\end{array}$ & 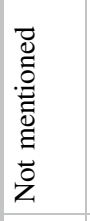 & 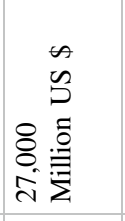 & 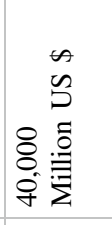 & 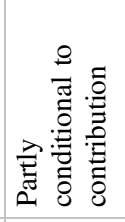 & 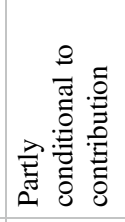 & 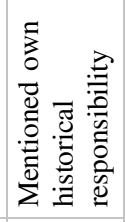 & 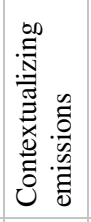 & 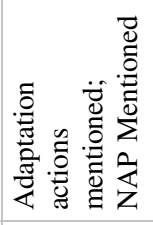 & 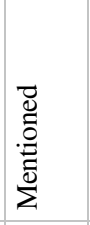 & 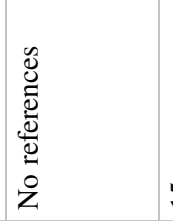 & 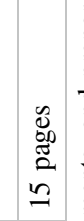 \\
\hline 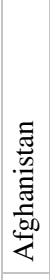 & 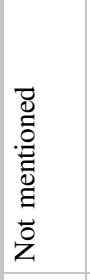 & 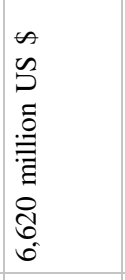 & $\begin{array}{l}\infty \\
0 \\
0 \\
0 \\
. \\
\vdots \\
\vdots \\
\vdots \\
8 \\
8 \\
= \\
=\end{array}$ & 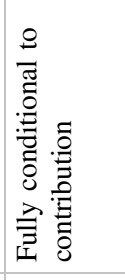 & 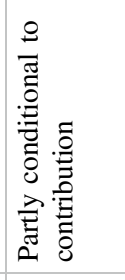 & 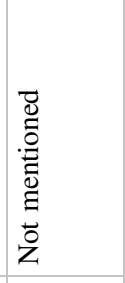 & 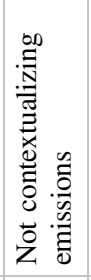 & 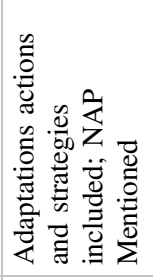 & 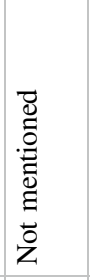 & 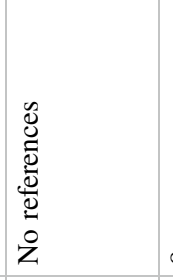 & 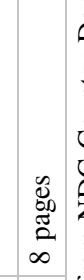 \\
\hline & 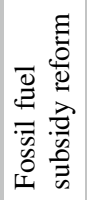 & 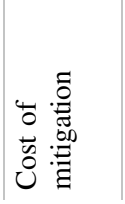 & 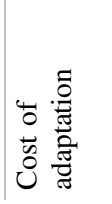 & 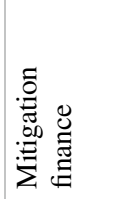 & 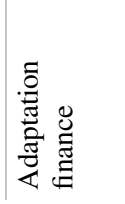 & 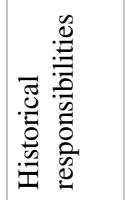 & 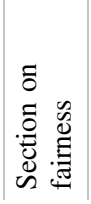 & 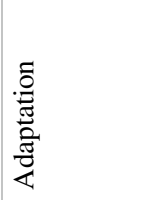 & 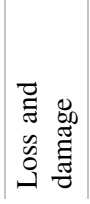 & 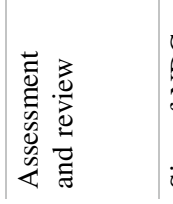 & 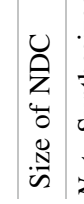 \\
\hline
\end{tabular}


The main targets and indicators listed by the chapter scientists were shared with policy makers, who were asked to answer two questions:

a. Are indicators as identified sufficient from a decision making point of view, or is there scope for enrichment?

b. What is the current (i.e., 2015 baseline) status on a quantitative scale (scale of 1-5) of each indicator? Are there variations across the HKH?

The assessment based on these two stage consultations, along with a literature review, are presented below thematically.

Climate: The increasing changes in mean annual temperature, high uncertainty around impact of climate change, regional differences such as higher warming over higher altitudes and faster warming in the eastern part of the $\mathrm{HKH}$ region are the increasing challenge of controlling such changes. Very high uncertainty in the total rainfall and monsoon periods with regional differences are also expected (Lutz et al. 2014). Neglect of linking air pollution and climate change issues have led to an absence of improved research in this area. Climate change, in conjunction with the challenge of the sustainable use of natural resources, poses a greater impediment for development in the HKH. Most of the countries have submitted INDCs giving commitments to take steps towards climate change mitigation and adaptation. With increasing extreme weather events, disaster proneness is expected to increase by 2030 with a higher loss of assets. However, with greater recognition of an increasing likelihood of disasters, emergency response and mechanisms for addressing disasters, the magnitude of life losses is going to be reduced. Appreciable attention has been given by all the countries under SDG 13 (Target 13.3) to gradually establish climate forecasting systems, improving coverage of meteorological early warnings, disaster prevention and reduction systems, and strengthen climate resilience. Additionally, the coupling of local and national mechanisms with appropriate communication and coordination systems, vitalizing local institutions, and appropriate policy instruments is necessary to achieve the desired goal of disaster risk reduction.

Natural Resources: Most of the HKH countries have among the highest levels of hunger and malnutrition in the world. It is projected that hunger and malnutrition will be totally eradicated for all by 2030, in particular for the poor, infants, and people in vulnerable situations, as part of SDG2. To achieve this through sustainable food production systems, implementation of resilient agricultural practices, addressing impacts of climate extreme events and disasters, land and soil quality management, and other related parameters of enhancing productivity will play important role. The supply side key challenges to agriculture include optimal land allocation and water use, minimising land degradation, urbanisation trend with increasing affluence and changing tastes of the population. The improvements in financial and credit support systems, agriculture marketing, effective extension services and post-harvest losses are also identified as very important factors.

Food availability and accessibility are also targets of strengthened local food systems and stable food supply from the plains. Improvement in local people's income, planned adaptations to climate change, and higher chances of collaborative food trade in the region also promote food availability and accessibility. The percentage of people who face hunger will also be substantially reduced due to effective food procurement, storage, and distribution systems and ensured equity in inter- and intra-household distribution of food. Reducing the percentage of people with malnutrition is going to be a difficult task unless improved food intake, people's knowledge on nutrition and health, dietary diversity and intake of micronutrients, health services (child- and mother-care and immunizations) and infrastructure (hospitals and health centres), and health environment (hygiene, safe drinking water, and improved sanitation) are all improved. The overall 2030 food security goals can be achieved with the support of effective governance systems and implementation, good infrastructure, and regional cooperation.

Water availability is expected to be on an increasing trend with increased natural flow under higher precipitation and melt conditions. However, the uncertainty over spatial and temporal distribution and increasing trends remains a challenge. Upstream water use for realizing national hydro potential will continue to increase and water quality will deteriorate over time. The higher water use for increased agriculture and urbanization might have implications for water availability outside the HKH. Due to lack of management of infrastructure and land use, the volume of reservoirs and spring flows will reduce. Against this background, universal provision of drinking water (Target 6.1) and sanitation coverage and the quality of water under SDG 12 as planned by 2030 is going to be critical. In countries like Afghanistan, Bhutan, India, and Pakistan, meeting the goal of improved sanitation is going to be a formidable challenge, especially in India, which aims to achieve $100 \%$ improvement by 2018. Similarly, most of the countries are far from providing quality water at international standards and ensuring universal access to piped water supply.

Many more large water-sharing agreements that take into account use of regional hydro potential, ecosystem flows, upstream-downstream issues, and sectoral water allocation issues in the region will emerge to facilitate meeting these 
challenges. Bilateral agreement (e.g., between India and other countries), stronger centralized maintenance of transboundary waters, rising investment in urban infrastructure, and strong, self-reliant local management are going to be greater driving factors of water governance. The policy implications and incentives for the trajectory of hydropower development, regulation and maintenance of ecosystem flows, and effective use of pre-monsoon flows for hydro and agricultural use are going to be critical. Improving water quality, electricity for withdrawing water, wastewater treatment, technical knowledge gaps and systems, infrastructure, O\&M cost, enforcement, soil erosion, and dam sedimentation are other intrinsic factors regulating the growth trends toward 2030.

The trends of ecosystem degradation by 2030 are going to be different across the region, with countries like Myanmar, Afghanistan, and Pakistan experiencing higher levels of degradation. Community-based initiatives like REDD+ in Nepal and Bhutan are going to play a significant role in the conservation of ecosystems and ensuring ecosystem flows. With accelerated climate change, there will be shifts in the growth and distribution patterns of high-value products at higher altitudes, affecting ecosystem services. In this context, countries like China, Myanmar, and Bhutan have made commitments to mitigate climate change impacts through forest-based enhanced carbon sink capacity to achieve the goals under SDG 13 and 15.

Social Systems: In order to avoid inequitable transformation, the targets of Goal 1 on Eradication of Poverty need to be supported with intricate and balanced actions among climate, sustainability, and poverty. Accordingly, the Goal (2) on food security, Goal (3) on access to healthcare, Goal (4) on education, Goal (6) on water and Goal (7) energy for all also covers issues related to poverty. Additionally, infrastructure development enabling capital formation and employment generation are addressed under Goals 9 and 11. As part of Goal 8 inclusive economic growth to enable income opportunities are targeted towards poverty reduction. While we discussed possible directions and challenges of these goals in the earlier sections, the HKH faces region-specific social and demographic challenges in bringing overall social change for poverty eradication, eliminating gender discrimination, and enhancing health and education, as explained below.

The current trends of increasing income due to people migrating into higher income jobs in both urban areas and outside the region, upcoming service sectors, tourism, and $\mathrm{M} / \mathrm{SMEs}$, and the consequent increase in purchasing power are expected to continue. Migration will also increase even if the population growth rate remains constant. On the other hand, great uncertainty exists about movement beyond 2020 and money flows due to extrinsic factors such as labour policies in the Gulf countries, a slowdown in Chinese growth, reduction in the construction boom, and so forth. Major challenges include increasing vulnerability to climate change, market dependency, difficulties of small farmers in securing finance for purchasing seeds and shifts in land use toward high-value crops. Male outmigration pushes women directly into activities relating to economic development in addition to their traditional roles. This change comes on top of the current top-down policy systems, in which there is lesser engagement of people from various social strata. This situation is going to be a challenge for achieving the 2030 SDGs unless a more inclusive policy-making process is followed. Therefore, there is a rising need for new dimensions of social inclusion in decision making processes by, among others, including this new female workforce in developmental activities. This inclusion will increase the acceptance by the local people and will help reduce poverty to achieve the SDGs by 2030.

The institutional setting in the region, especially in the mountains, is very spread out and weak at the subnational level. It is necessary to have decentralized adaptive governance with institutional settings that enable effective governance mechanisms for adaptation by 2030 , especially at the subnational level. Ecological fragility is very strongly distributed in the region. At the lower level, more holistic and science-based policies are needed; for example, REDD + might take away land and lead to more poverty for local inhabitants. Development of more resilient mountain communities, adaptation strategies that ensure equal engagement of women and men, building capacities of institutions involved in planning and implementation, and access to global finance systems should be addressed by 2030 to minimize social disparities and inequalities.

Considering the minimal progress made in combating gender discrimination over the last decade in the HKH, institutional and policy mechanisms are identified by all countries to end discrimination against all women and girls covering all forms (SDG 5). The elements like women's and girls' rights to education, social welfare, labour security and medical care are identified as important for achieving this goal. Raising public awareness and commitment on gender equality and complete eradication of discrimination and prejudice against women and girls is also considered crucial.

Economy: As part of SDG 6, most of the countries envisages to provide reliable, affordable, sustainable, and modern energy services for all by 2030. Continued reforms and restructuring of urban and rural power grids, focusing on upgrading of grids for small towns and rural centres, and ensuring full rural power coverage are advocated as critical steps. Advanced welfare-oriented energy policy that promotes benefit-sharing mechanisms, accelerating poverty reduction programmes through photovoltaic technology, and 
energy development in poverty-stricken areas are considered important. Increasing the share of non-fossil fuels in primary energy consumption, optimizing the energy mix by improving fossil-fuel efficiency, and increasing the share of clean energy consumption are some of the measures for ensuring that non-fossil fuels and natural gas become the main energy sources. Improved hydropower generation will leapfrog electrification, but political issues still impede the possibility of shifting from biomass to electrification.

These efforts will cost a lot for countries like Bangladesh, requiring an investment of USD 26.6 billion up to 2030 to cut coal production-based carbon emissions. On the other hand, the projected cost for India of meeting the goals of SDG 6 is USD 854 billion with estimated gap of USD 406 billion along with high dependence on foreign imports. The dependence on alternative energy sources beyond fossil fuels is also being necessitated due to falling prices of renewable energy and rise of coal market prices. The improved financial services, affordable credit, integration into value chains and markets are identified as essential elements to promote small and medium scale (SMEs) under SDG 9/Target 9.3. In this context, the SDG report of India and Bhutan National Development Plan clearly identified that inadequate access to financial resources is one of the main challenges for the growth and development of SMEs, especially during the periods of economic crisis. The need for development, transformation, and upgrading of SMEs through mass entrepreneurship and innovation is emphasised as part of China SMEs developmental plans. The provision of intellectual support and building effective platforms of international cooperation are also identified as critical for the sustainable development of SMEs.

Country level challenges: Pakistan plans to progress into Upper Middle-Income countries by 2025 through addressing SDG goals on zero poverty and hunger, universal access to education health services, clean water and sanitation and modern energy services. The people-centred innovative, coordinated, green, open, and shared development is considered as important in China to implement the 2030 agenda and promote sustainable development. The concept of inclusiveness, equitability along with the spirit of a welfare and prosperity are reported as fundamentals for Nepal to become middle-income country by 2030 . Myanmar plans to have an effective financial system and services for all people and positive shifts towards from agriculture to services sector and industry to achieve SDG goals of 2030. It is also to be noted that most of the reports have limited focus on HKH mountain systems.

\section{Box 4.3 Summary of (I)NDCs related to climate change mitigation of HKH countries}

Afghanistan: Reduce 2030 GHG emissions by $13.6 \%$ as against business as usual (BAU) 2030 scenario, with external support as condition (Islamic Republic of Afghanistan 2015).

Bangladesh: Unconditional and conditional GHG emission reduction scenario by 2030 from BAU levels in the power, transport, and industry sectors. The unconditional scenario targets to reduce emissions by $5 \%$ based on existing resources. A conditional $15 \%$ reduction is targeted subject to appropriate international support (Government of the People's Republic of Bangladesh 2015).

Bhutan: Intends to remain carbon neutral by maintaining emissions below the estimated 6.3 million tons of annual forest carbon sequestration. The export of electricity from clean hydropower projects is also expected to offset up to 22.4 million tons of $\mathrm{CO}_{2}$ per year by 2025 in the region (INDC, Bhutan 2015).

China: $60-65 \%$ reduction in $\mathrm{CO}_{2}$ emissions per unit of GDP (carbon intensity) against 2005 levels and 4.5 billion cubic metres increase in its forest carbon stock volume from 2005 levels (Republic of China 2015).

India: Reduction of 20-25\% in emissions intensity of its GDP by 2020 with reference to 2005 base levels as a voluntary goal having no binding mitigation obligations (Government of India 2015b).

Myanmar: Section 4.2.1-Mitigation actions, envisages plans with a condition of international support to achieve sustainable development needs for fulfilling its contribution to reduce future emissions as part of global action (The Republic of the Union of Myanmar 2015).

Nepal: Nepal intends to pursue and support the efforts to limit the rise in temperature to well below $2{ }^{\circ} \mathrm{C}$ and develop Low Carbon Economic Development Strategies to promote future economic development through a low carbon economy (Government of Nepal 2016). Pakistan: It intends to reduce GHG emissions of 2030 in relation to BAU in 2030 in different sectors such as Energy Supply: 37\%, Energy Demand: 22\% Transportation: 8\%; Agriculture and Forestry: 5.5\% (Government of Pakistan 2015). 


\subsection{Two Paths Toward a Prosperous HKH}

Potential pathways leading toward the desired prosperous HKH are myriad and overlapping, but participants in the consultative workshops developed qualitative assessments on how and why the HKH future might unfold in certain directions.

The outcome of these consultations was integrated with the trends, possibilities, and trade-offs coming from related chapters of this assessment. A two-step interactive process with chapter teams of this assessment and decision makers has provided the necessary data to develop the pathways. Interaction with researchers engaged with writing the chapters of this assessment and decision makers revolved around two major questions:

- What direction are the key indicators on challenges (e.g., access to water, energy) and opportunities (e.g., water availability, biodiversity) likely to take in each $\mathrm{HKH}$ 2080 scenario as compared to the 2015 baseline, and how strong is this change on a scale of 1-5?

- What additional strategies can help in this transition?

Analysis of the responses clearly showed that there are diverging views among scientists, experts, and decision makers on how the HKH may prosper. These different points of view clearly indicate that there can be more than one pathway toward a prosperous future.

Pathways usually differ in terms of trade-offs, opportunities, and challenges, but still lead to the same outcome. Pathways try to answer questions such as: "What policy actions can create an enabling condition for progress?", "What kind of technological options might be available to make this progress possible?", or "Which economic sectors, natural resources, and developmental actors can play a central role in ensuring that progress is made in the desired direction?" A pathway is described here as a set of actions and combinations of actions that a decision maker (individual, country, business, policy maker) can take.

Here, two broad pathways are presented to facilitate envisioning of the future and to support an effective decision-making process toward a prosperous HKH. The pathways differ from each other in the trade-offs among policy choices, institutional arrangements, and technology choices that are to be made. However, some actions are common to both pathways. Actual effectiveness of the pathways will depend on multiple issues like social acceptance, political agreements, and investment decisions. Based on the consultative workshop participants' feedback, the characteristic actions, trade-offs, benefits, and risks associated with the pathways are described below.
Pathway 1-Large scale investments including regional cooperation: It is possible to get to the prosperous scenario using the HKH's naturally available resources by according higher priority to centralized large-scale power, communication, infrastructure, and development projects. Water and energy are going to be critical for ensuring energy access and food security, and for eliminating poverty. However, this will require large-scale financial and skilled human resource mobilization, collaboration of both state and large corporate, non-state actors for financing the actions, and national and international funding. Widespread communication and mobility that enhance infrastructure, trade and cross-border resource sharing, and institutions for governing the collaboration and cooperation across regions and within the region will be the essential features of this pathway.

Pathway 2-Bottom-up investments with cooperation across multiple levels: It is also possible to get to the prosperous scenario using the HKH's critical resourcesenergy and water-through higher prioritization of small-scale, decentralized, local or national developmental actions and projects. However, this would require the involvement of a large number of developmental and social actors nationally and sub-nationally. Also, a multilevel governance structure will be needed to address local diversities, to mobilize financial resources for a large number of projects of different scales, and (more than for Pathway 1) to monitor the progress and ensure it is in line with the scenario goals.

Based on the assessment of the feedback received from consultation workshops and the content of this assessment report, it is clear that there cannot be one single best possible set of actions or a single pathway for decision makers to minimize the challenges and seize the opportunities for the $\mathrm{HKH}$ in keeping with the long-term goal of prosperity. Multiple actions will need to be followed simultaneously.

It is crucial that visioning and strategic planning start now to enable the implementation of actions beyond 2030 by decision makers. To decide on the choice of pathways, there is need for prior analysis, understanding, and recognition of the HKH's unique and emerging opportunities and challenges. The challenges in the HKH are large, and overcoming them can help the HKH prosper in a sustainable manner. At the same time, there are numerous opportunities for the region. Based on the information on the variety of opportunities and supplementary resources needed to implement these opportunities, detailed actions and the way forward are summarised in Table 4.4. The description of the set of actions for alternative pathways toward 2050 provides a guideline for decision makers in the region. However, each action has varying sources and levels of risks. It is important 
to be aware of the risks so that risk mitigation strategies can be developed and implemented. Awareness of these risks can also help in guiding the actual implementation decision.

The two alternative pathways are not completely mutually exclusive, so it is possible for the alternative pathways to have some common actions. Actions have thus been categorized under three headings: "Specific actions: how pathways differ", "Common set of actions", and "Actions to be avoided". The two pathways are mainly differentiated by these specific actions.

\subsubsection{Major Emerging Opportunities in the HKH}

Major opportunities are emerging in the region due to climatic change response strategies, historical developmental actions, and multi-dimensional commitments made by national governments for the period until 2030 to attain SDG targets. The opportunities are summarised below:

Water resource availability is expected to improve in the HKH (Chaps. 3, 7 and 8): Increased flow is expected mainly because of increased precipitation, although glacial melt will decrease. However, this increased flow will happen with greater seasonal variability across countries and within countries in the region and with a changing pattern over time. An exception is the Indus basin because in the Indus river system, the main contribution is from snow and ice melt and to a lesser degree from rainfall.

Multiple new trade potentials from the HKH are going to increase (Chaps. 6, 8, 9 and 12): As the income of mountain people improves, the demand level and pattern will change. However, in the case of a disaster or crisis combined with the rising demand, food security can only be achieved through increased trade and a better distribution system. Electricity trade and water transfer within and between the $\mathrm{HKH}$ and non-HKH regions will increase with increasing economic activity, population, and income growth.

Non-farm activity-based livelihood diversification is strongly emerging (Chaps. 5, 6, 9, 12 and 15): People are changing their livelihood by moving toward high-paying cash crop farming and the service sector and by migrating to other regions. Dietary diversity resulting from income increase drives the need for processing and manufacturing industries. Demand for the aesthetic value of the HKH's unique cultural diversity, ecosystem, and services has given rise to high demand for a well-regulated tourism industry and infrastructure managed by skilled human resources.

Energy demand is going to grow significantly, while the potential for renewable and sustainable energy is also increasing (Chaps. 6, 8 and 9): The accelerated development of hydropower can help countries in attaining transformative change in achieving a carbon-free $24 \times 7$ power supply.
This will help to avoid small steps and facilitate leapfrogging in attaining a secure and reliable power supply, clean cooking, and space heating, which will eliminate indoor air pollution and protect the health of women and children. This is not in conflict with a decentralized/micro grid for the high mountains.

Community-based institutions to manage natural resources (Chaps. 8 and 16): These have emerged as a major trend globally, and the HKH already has a long history of working with such institutions.

Need for cooperation across various levels in the region is emerging quickly (Chap. 16).

\subsubsection{Two Pathways and Distinguishing Actions}

Identifying strategic actions to seize the emerging opportunities is crucial for achieving prosperity in a time-bound manner. Table $4.4 \mathrm{a}, \mathrm{b}$ list actions identified during the consultative workshops as crucial for a prosperous HKH. Knowledge of varying benefits, investment, and governance needs and the multiple sources and nature of risks associated with actions and their implementation strategies help in making decisions. These are listed in Table $4.4 \mathrm{a}, \mathrm{b}$ for each of the pathways.

Pathway 1 consists of strategic actions based on globally available technology and knowledge to meet leapfrog growth imperatives in the HKH region. It takes into account mountain-specific resources, cultural diversity, and niche product potentials, but also identifies the need for cross-regional cooperation, institutions, and finance. Demand for access to modern energy and energy security in the region indicates the need for energy system transformation. One way to leapfrog on the supply side with energy security in the HKH region could be to achieve $100 \%$ hydropower share (Chap. 6) for the HKH region in the longer run. This will help to promote modern industrial growth and advance mountain mobility and human wellbeing through such changes as cooking fuel leapfrogging from biomass to clean, renewable electric supply, along with self-reliance. Necessary actions have to be taken now to ensure a larger allocation of water for hydropower generation in the HKH region (Chaps. 6 and 8) in the coming years. This can be done by prioritizing large-scale cross-border infrastructure building for large-scale hydropower projects (Chap. 16) with a regional grid and grid integration. For example, the HKH grid can be connected to India's northern regional grid or national grid, or the national grids of other countries. The need for large knowledge capital, technology, and financial capital can be met through more global cooperation between the HKH and non-HKH regions (Chap. 6). Governance of such projects will need cross-border harmonization through power distribution arrangements, power 


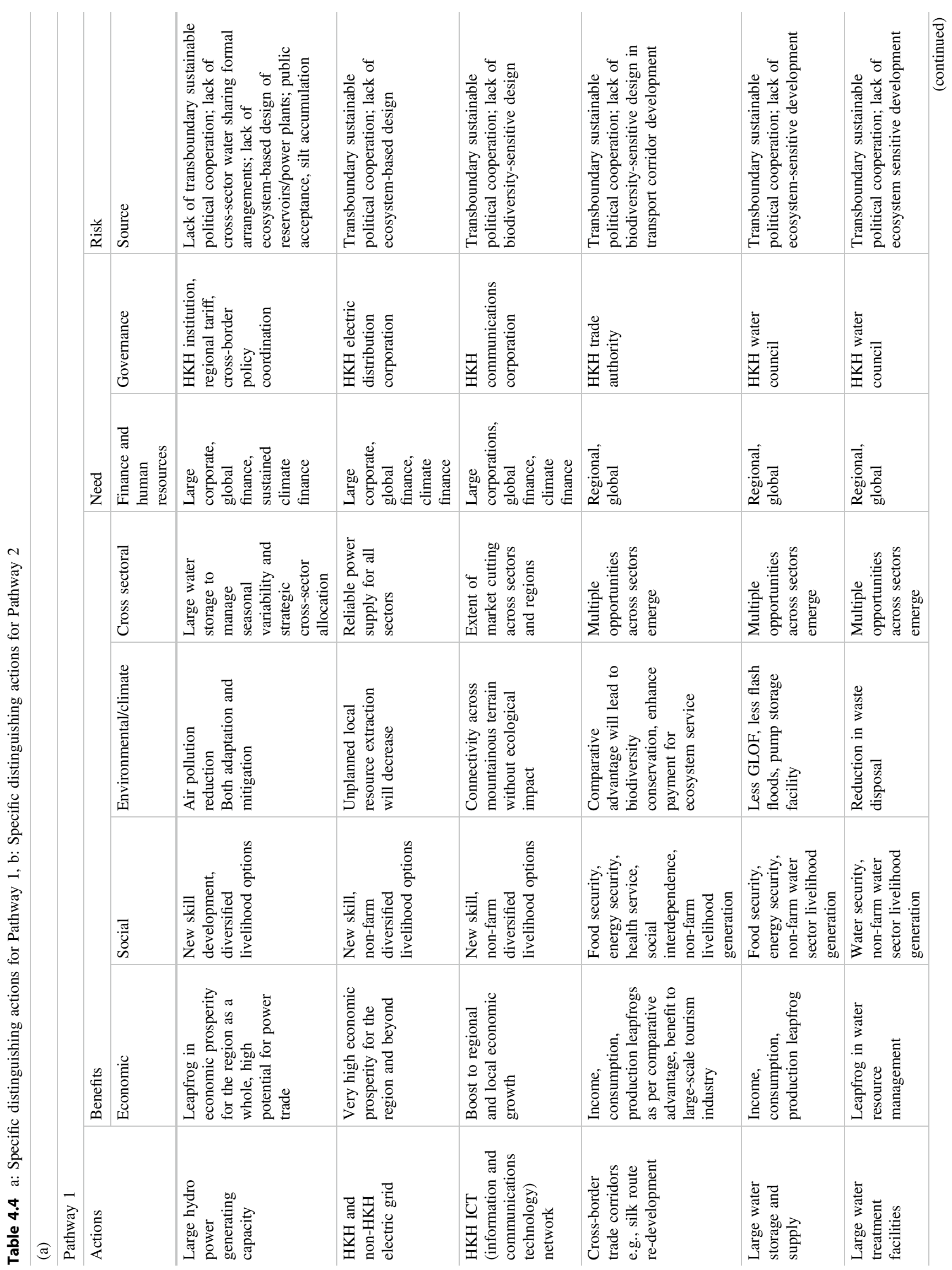




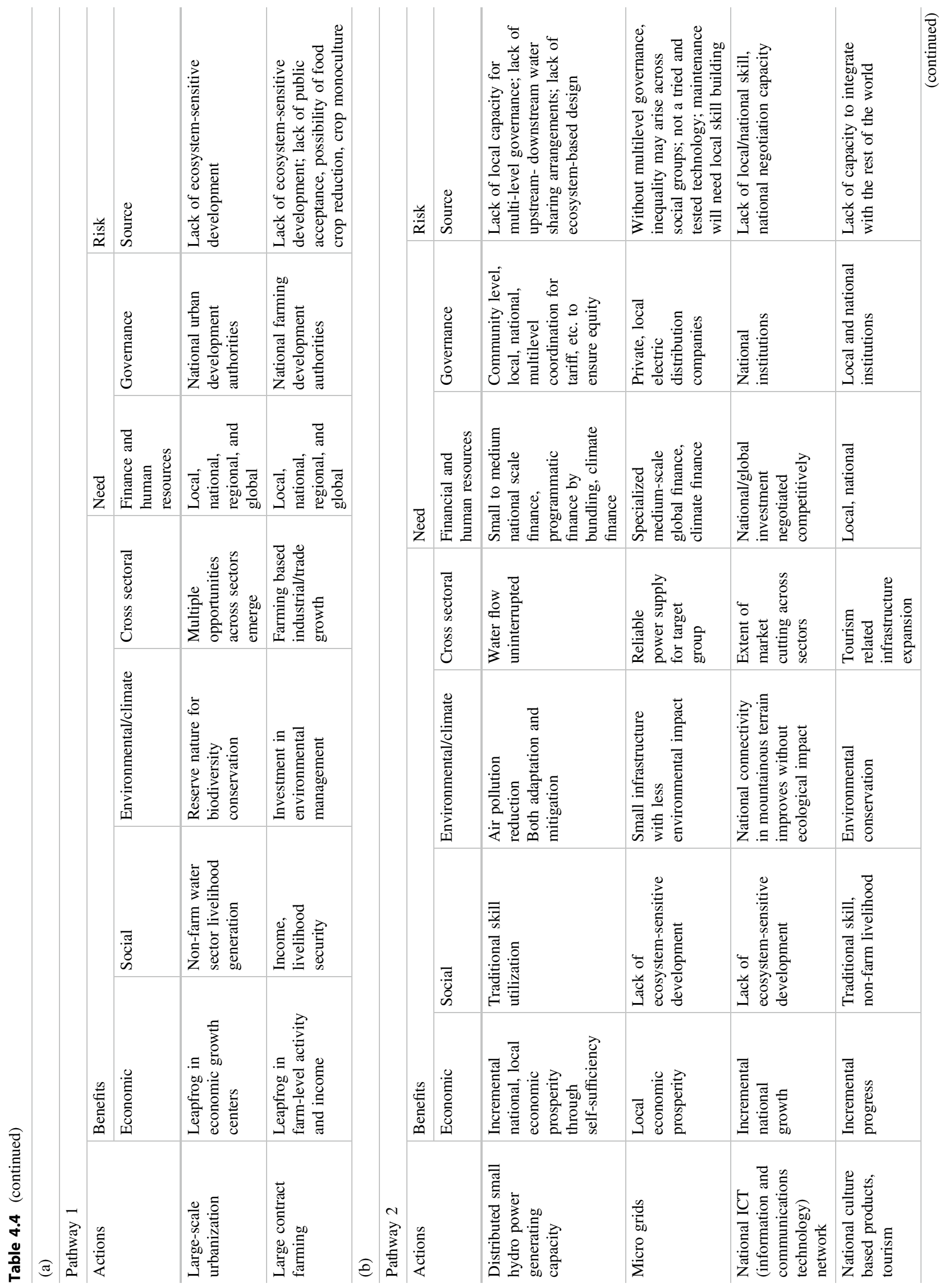




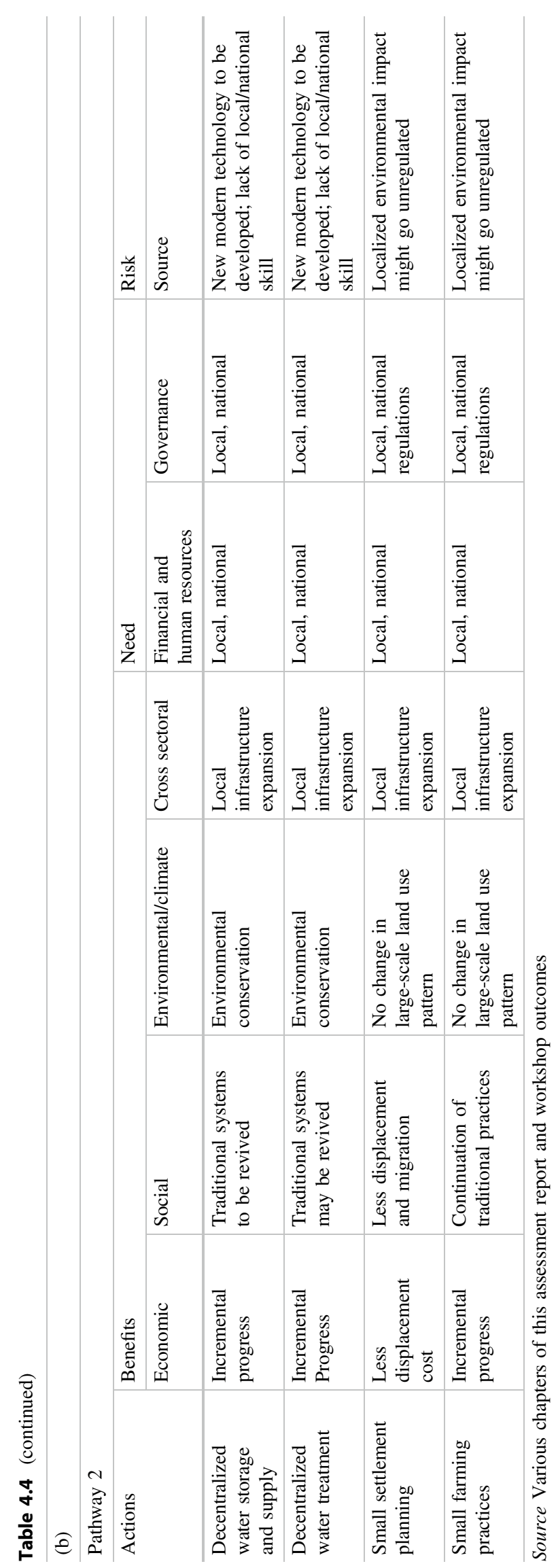


purchase agreements, power tariffs, incentive designs, and policies. Many mountain tracts will need micro grids with small hydro-electricity (hydel) generation. There will be a need for new HKH financial institutions like BRICs bank and HKH regional bank.

With high priority accorded to hydropower generation, water resource sharing with other competing demand sectors will need special attention and concrete actions. More allocation of water for the power sector will imply a trade-off with water allocation for increased demand for water in urban areas, agriculture, and food (Chap. 8). However, with the penetration of new wastewater treatment technology and water quality management of available surface and groundwater available water supply will increase. Adoption of water-efficient technologies for irrigation and cropping patterns shifting away from paddy cultivation will reduce demand for water in agriculture sector. These sectors can be managed with a relatively smaller quantity of water (Chap. 8 ). Appliance standard policies need to be in place to achieve water efficiency. There is a need for cross-country learning, best practice sharing and technical knowledge sharing (Chap. 6). Building larger water storage systems to manage seasonal variability in water supply could be a solution. These storage systems can be used for more hydro power generation, which implies scope for wider power trade. The latter will need major new economic cooperation in the region. More cross-country collaboration and human resource sharing between the $\mathrm{HKH}$ and non-HKH areas of the countries will also be necessary to ensure access to sustainable energy and water in the longer run.

Pathway 2 is also comprised by various strategic actions, although at a different scale. To meet the rapidly growing demand for access to modern energy and energy security of the region through more renewable energy, there can be decentralized generation and micro grids, one of which will continue to be hydropower generation, mostly with small hydel projects. The current centralized grid will continue, but newer decentralized generation will dominate the action agenda at the national and sub-national scale (Chap. 6). The energy supply source mix will be diversified through solar and advanced biomass use, with less water allocated for hydropower generation. Water allocation may result from bilateral or trilateral upstream-downstream water sharing agreements within and across borders. Such projects will need multi-level governance and more country-specific power tariff rationalization and national incentive designs. Small, decentralized water storage systems managed by the community and a multi-level governance mechanism should be in place to avoid the risk of failure.

Energy need for the expansion of small and medium enterprises (Chap. 6) will need special grid setups for reliable, dedicated supply. To ensure self-reliance in energy supply for each economic activity, special monitoring and maintenance skills will be required and appropriate capacity will have to be built. More multi-level governance within each country will be needed to ensure self-sufficiency and reliability in supply. Power service delivery from multiple sources (e.g., solar, biomass, hydro) will need a multi-skill development effort. Financial capital and institutions will need to deal with multiple investors. However, the need for knowledge capital, technology, and financial capital can be met through wider cooperation between the HKH and non-HKH regions (Chap. 16). Overarching national regulations and norms will have an important role and will need to be developed. However, upstream-downstream resource sharing issues will need to be resolved across and within the countries in the HKH.

\subsubsection{Two Pathways but Common Actions}

The actions described as part of each pathway can of course be used along either pathway. It is likely that irrespective of the pathway decision makers decide to follow, these actions will need to be implemented to bring prosperity to the HKH. Table 4.5 lists the actions that are likely required for both pathways.

Table 4.5 Actions common to both pathways

\begin{tabular}{l|l}
\hline Actions & Challenges to overcome \\
\hline Build better health infrastructure & $\begin{array}{l}\text { Malnutrition, poor health, } \\
\text { poverty }\end{array}$ \\
\hline Create food banks & $\begin{array}{l}\text { Increase food security across } \\
\text { seasons }\end{array}$ \\
\hline $\begin{array}{l}\text { Investing high-skill creation at } \\
\text { various levels }\end{array}$ & $\begin{array}{l}\text { Creation of new non-farm } \\
\text { activities }\end{array}$ \\
\hline $\begin{array}{l}\text { Develop migration laws across } \\
\text { regions to facilitate mobility }\end{array}$ & $\begin{array}{l}\text { Improve livelihood } \\
\text { diversification and remittance } \\
\text { flow }\end{array}$ \\
\hline $\begin{array}{l}\text { Create appliance standards for } \\
\text { efficient irrigation practices to } \\
\text { increase penetration rate }\end{array}$ & $\begin{array}{l}\text { Enhancement of energy as well } \\
\text { as water use efficiency and } \\
\text { enhancement of water storage } \\
\text { capacity }\end{array}$ \\
\hline $\begin{array}{l}\text { Promote specific products that } \\
\text { reflect local diversity }\end{array}$ & $\begin{array}{l}\text { Increase in food and nutrition } \\
\text { security }\end{array}$ \\
\hline $\begin{array}{l}\text { Establish a seed bank } \\
\text { Improve mobility sector }\end{array}$ & $\begin{array}{l}\text { Loss of biodiversity } \\
\text { mountain supply system, which } \\
\text { implies cross-country } \\
\text { collaboration, trade } \\
\text { negotiations, policies, pricing } \\
\text { to ensure cross-border } \\
\text { movement }\end{array}$ \\
\hline
\end{tabular}




\subsubsection{Actions to Avoid Downhill and Business as Usual (BAU) Scenarios}

Clearly conscious evidence-based strategic decisions, mechanisms, and actions are needed no matter which of the potential pathways is adopted to make sure the HKH does not move toward undesirable scenarios. Complex challenges require sustained effort and progressive visioning over time to ensure progress toward prosperity, and it is clear that some actions will certainly undermine progress toward prosperity (Table 4.6).

Table 4.6 Actions to be avoided

\begin{tabular}{|c|c|}
\hline Actions to be avoided & Benefits/avoided risks \\
\hline Water related conflicts & $\begin{array}{l}\text { Risk of lack of economic growth and } \\
\text { loss of livelihood is avoided. Conflict } \\
\text { resolution mechanisms based on } \\
\text { scientific evidence should be in place } \\
\text { at local, national, and regional levels }\end{array}$ \\
\hline $\begin{array}{l}\text { Poor maintenance of water } \\
\text { storage infrastructure }\end{array}$ & $\begin{array}{l}\text { Risk of reduction of water volume and } \\
\text { reservoir capacity because of increased } \\
\text { sedimentation }\end{array}$ \\
\hline Closed deal of Indus treaty & $\begin{array}{l}\text { Lost opportunity to implement } \\
\text { efficient and equitable water sharing } \\
\text { based on new HKH-specific scientific } \\
\text { evidence and changing realities }\end{array}$ \\
\hline Energy supply scarcity & $\begin{array}{l}\text { Inefficient management of water } \\
\text { supply and health infrastructure } \\
\text { systems }\end{array}$ \\
\hline $\begin{array}{l}\text { Use of inefficient } \\
\text { technology }\end{array}$ & $\begin{array}{l}\text { Increased waste across all sectors and } \\
\text { missed opportunity of low-cost } \\
\text { resource availability, e.g., energy } \\
\text { supply and demand sectors, water, } \\
\text { irrigation }\end{array}$ \\
\hline $\begin{array}{l}\text { Unhealthy and non-diverse } \\
\text { food habits }\end{array}$ & $\begin{array}{l}\text { Health risk. Changing income and food } \\
\text { preference towards vegetables and } \\
\text { non-paddy crops can be an incentive } \\
\text { for choice of "climate proof" crops }\end{array}$ \\
\hline $\begin{array}{l}\text { Inequitable food } \\
\text { distribution }\end{array}$ & $\begin{array}{l}\text { Increased risk of conflicts because of } \\
\text { lack of food }\end{array}$ \\
\hline Top-down policy & $\begin{array}{l}\text { No buy-in by the local people if } \\
\text { top-down policy is used without } \\
\text { engagement with the public }\end{array}$ \\
\hline Gender bias & $\begin{array}{l}\text { Risk of inequity and ineffective uptake } \\
\text { of projects. Equal engagement of men } \\
\text { and women is needed in climate } \\
\text { adaptation projects for them to be } \\
\text { effective }\end{array}$ \\
\hline Low adaptation capacity & $\begin{array}{l}\text { Risk of ineffective adaptation projects. } \\
\text { If institutions and capacity for } \\
\text { adaptation in the mountains remain } \\
\text { very minimal, vulnerability to climate } \\
\text { change will remain high }\end{array}$ \\
\hline Degradation of ecosystems & $\begin{array}{l}\text { Loss of biodiversity and quality of life. } \\
\text { Unless degradation of ecosystem is } \\
\text { avoided, decentralized bottom-up } \\
\text { actions and governance will emerge }\end{array}$ \\
\hline
\end{tabular}

\subsection{Beyond 2050 to 2080: Knowledge Gaps and Ways Forward}

The decisions and choice of actions discussed in Sect. 4.4 are going to be important in realizing the 2080 scenario of a prosperous HKH. Unless the suggested actions are implemented, the downhill or business as usual scenarios are likely to prevail and will undermine prosperity beyond 2050 . For the two pathways mentioned, there can be many combinations of actions by which prosperity can be achieved.

Decisions are going to be strategic through various levels of cooperation and at clear intervals. Otherwise, the chances of achieving prosperity will be uncertain as spiralling conflicts can have a cumulative effect, leading to a pathway that diverges from long-term prosperity. The most important decision on the level of cooperation will also be guided by the decision of the chosen pathway, technology, and resource sharing. However, regional cooperation on resource sharing will not guarantee prosperity for the region unless global mitigations are guaranteed. The expert and stakeholder consultations clearly brought out the highest pessimism in this context. However, the Paris Agreement, if adequately implemented, can help in achieving the prosperous scenario.

As this chapter has developed future long-term scenarios and considers transformation toward long-term prosperity, the knowledge gaps described here also focus on the long-term context. As this effort is a first of its kind, long-term scenario development for the $\mathrm{HKH}$, it is clear that a more extensive process covering many more stakeholders needs to be undertaken. Such a process will further improve the understanding of the possible strategies that take into consideration technological, socio-political, and economic aspects. In this context, more refined indicator development through a continuous process of participatory engagement in the region might be useful.

The scenario and pathway building reflected in this chapter has been primarily a qualitative process, but one based on bottom-up, participatory, consultative shared narratives and scoring. There is no top-down regional impact assessment model being used to quantify the qualitative scenarios and pathways. Although qualitative storyline building and strategy identification through wider participation in the region remains a major tool for continued use in the future, developing a regional assessment model for quantitative assessment specifically for the HKH would also be advisable to better inform decisions. For example, risks associated with various actions that emerged through the consultative process across pathways are the least understood. An emission assessment of large-scale interventions, an economic assessment for identifying the least costly and most beneficial pathway, and for understanding adaptation and mitigation costs along the pathways, will help to improve future decision making. 


\section{References}

Afghanistan Survey. (2013). National nutrition survey of Afghanistan, Survey Report. https://reliefweb.int/sites/reliefweb.int/files/ resources/Report\%20NNS\%20Afghanistan\%202013\%20(July\% 2026-14).pdf.

Asian Development Bank. (2011). Poverty Data. https://www.adb.org/ countries/main

Asian Development Bank. (2013). Food security in Asia and the Pacific. Manila: Asian Development Bank.

Asian Development Bank. (2014). Myanmar unlocking the potential. Country diagnostic study. Mandaluyong City, Philippines: Economics and Research Department. https://www.adb.org/sites/ default/files/publication/42870/myanmar-unlocking-potential.pdf.

Asian Development Bank. (2015). Energy outlook for Asian and Pacific. Manila: Asian Development Bank.

Asian Development Bank. (2016). Asian development outlook 2016 Asia's potential growth. Manila: Asian Development Bank.

FAO. (2010). Asia-Pacific forests and forestry to 2020. Bangkok: Food and Agriculture Organization of the United Nations. http://www. fao.org/docrep/012/i1594e/i1594e00.htm.

FAO. (2012). Statistical yearbook. Rome: Food and Agriculture Organization of the United Nations. http://www.fao.org/docrep/ 015/i2490e/i2490e00.htm.

Frontier Myanmar. (2017). https://frontiermyanmar.net $/ \mathrm{mm} /$ node $/ 4278$.

Gallopín, G. C. (2012). Five stylized scenarios. Global water futures, 2050. France: UNESCO. http://unesdoc.unesco.org/images/0021/ 002153/215380e.pdf.

Government of India. (2015a). Achieving the sustainable development goals in India. A study of financial requirements and gaps (2015). New Delhi: Ministry of Environment, Forest and Climate Change, Government of India.http://www.devalt.org/images/L3_ProjectPdfs/ AchievingSDGsinIndia_DA_21Sept.pdf?mid=6\&sid=28.

Government of India. (2015b). Intended nationally determined contributions-India. Delhi: Ministry of Environment, Forest, and Climate Change. http://www4.unfccc.int/ndcregistry/ PublishedDocuments/India\%20First/INDIA\%20INDC\%20TO\% 20UNFCCC.pdf.

Government of India. (2016a). The Indus Waters Treaty. New Delhi: Ministry of External Affairs. http://mea.gov.in/bilateral-documents. htm?dtl/6439/Indus.

Government of India. (2016b). Energy statistics. New Delhi: Ministry of Statistics and Programme Implementation. http://www.mospi.nic. in/sites/default/files/publication_reports/Energy_statistics_2016. pdf?download $=1$.

Government of India Report. (2017). https://www.hindustantimes.com/ india-news/6-3-crore-indians-do-not-have-access-to-clean-drinkingwater/story-dWIEyP962FnM8Mturbc52N.html.

Government of Nepal. (2015). Sustainable development goals 2016 2030 national (preliminary) report. Kathmandu: National Planning Commission. http://www.np.undp.org/content/dam/nepal/docs/ reports/SDG\%20final\%20report-nepal.pdf.

Government of Nepal. (2016). Intended nationally determined contributions - Nepal. Kathmandu: Ministry of Population and Environment. http://www4.unfccc.int/Submissions/INDC/Published\% 20Documents/Nepal/1/Nepal_INDC_08Feb_2016.pdf.

Government of Pakistan. (2013). Pakistan 2025 one nation one vision. Islamabad: Ministry of Planning, Development and Reform. http:// fics.seecs.edu.pk/Vision/Vision-2025/Pakistan-Vision-2025.pdf.

Government of Pakistan. (2015). Intended nationally determined contributions-Pakistan. Islamabad: Ministry of Climate Change. http://www4.unfccc.int/ndcregistry/PublishedDocuments/Pakistan $\% 20$ First/Pak-INDC.pdf.

Government of People's Republic of Bangladesh. (2012). Rio+20 Bangladesh National Sustainable Development. Peoples' Republic of Bangladesh, Bangladesh Secretariat Dhaka 1000, Bangladesh: Ministry of Environment and Forests. https://policy. asiapacificenergy.org/sites/default/files/Rio\%2B20_Bangladesh_ reduced.pdf.

Government of the People's Republic of Bangladesh. (2015). Intended nationally determined contributions-Bangladesh. Dhaka: Ministry of Environment and Forests (MOEF) Government of the People's Republic of Bangladesh. http://www4.unfccc.int/ndcregistry/ PublishedDocuments/Bangladesh\%20First/INDC_2015_of_ Bangladesh.pdf.

ICAD. (2018). Bangladesh: Country Profile on Nutrition and Child Stunting Trends. https://ec.europa.eu/europeaid/bangladeshnutrition-country-fiche-and-child-stunting-trends_en.

International Monetary Fund. (2016). World economic outlook: Subdued demand: Symptoms and remedies. Washington DC: International Monetary Fund.

IPCC. (2013). Climate change 2013: The physical science basis. In T. F. Stocker, D. Qin, G.-K. Plattner, M. Tignor, S. K. Allen, J. Boschung, A. Nauels, Y. Xia, V. Bex, \& P. M. Midgley (Eds.), Contribution of Working Group I to the Fifth Assessment Report of the Intergovernmental Panel on Climate Change (1535 pp.). Cambridge, United Kingdom and New York, NY, USA: Cambridge University Press. https://www.ipcc.ch/pdf/assessment-report/ar5/ wg1/WG1AR5_Frontmatter_FINAL.pdf.

Islamic Republic of Afghanistan. (2012). Millennium development goals report. Kabul, Afghanistan: Ministry of Economy. http:// www.af.undp.org/content/afghanistan/en/home/library/mdg/MDGsreport-2012.html.

Islamic Republic of Afghanistan. (2015). Intended nationally determined contributions -Afghanistan. Kabul: Islamic Republic of Afghanistan. http://www4.unfccc.int/ndcregistry/PublishedDocuments/ Afghanistan\%20First/INDC_AFG_20150927_FINAL.pdf.

Johansson, T. B., Patwardhan, A. P., Nakićenović, N., \& Gomez-Echeverri, L. (Eds.). (2012). Global energy assessment: Toward a sustainable future. Cambridge, UK: Cambridge University Press.

Lutz, A. F., Immerzeel, W. W., Shrestha, A. B., \& Bierkens, M. F. P. (2014). Consistent increase in High Asia's runoff due to increasing glacier melt and precipitation. Nature Climate Change, 4 (7), 587-592.

Moss, R. H., Edmonds, J. A., Hibbard, K. A., Manning, M. R., Rose, S. K., Van Vuuren, D. P., et al. (2010). The next generation of scenarios for climate change research and assessment. Nature, 463 (7282), 747-756.

Nakićenović, N., \& Swart, R. (2000). Special report on emissions scenarios: A special report of Working Group III of the Intergovernmental Panel on Climate Change. Cambridge, UK: Cambridge University Press.

Nakicenovic, N., Lempert, R. J., \& Janetos, A. C. (2014). A framework for the development of new socio-economic scenarios for climate change research: Introductory essay. Climatic Change, 122(3), 351-361.

O’Neill, B. C., Kriegler, E., Riahi, K., Ebi, K. L., Hallegatte, S., Carter, T. R., et al. (2014). A new scenario framework for climate change research: The concept of shared socioeconomic pathways. Climatic Change, 122(3), 387-400.

OECD. (2016). Economic outlook for Southeast Asia, China and India 2016: Enhancing regional ties. Paris: Organization for Economic Co-operation and Development. http://www.oecd.org/dev/asiapacific/SAEO2016_Overview\%20with\%20cover\%20light.pdf.

OECD/FAO. (2016). OECD-FAO agricultural outlook 2016-2025. Paris: OECD Publishing. http://dx.doi.org/10.1787/agr_outlook-2016-en.

OECD/IEA. (2016). World energy outlook. France: International Energy Agency. https://www.iea.org/publications/freepublications/ publication/WorldEnergyOutlook2016ExecutiveSummaryEnglish. pdf. 
Pachauri, S., Rao, N. D., Nagai, Y., \& Riahi, K. (2012). Access to modern energy: Assessment and outlook for developing and emerging regions. Laxenburg, Austria: IIASA.

Parry, M., Palutikof, O. F., van der Linden, Paul, J., \& Hanson, C. E. (2007). Climate change 2007: Impacts, adaptation and vulnerability. Cambridge, UK: Cambridge University Press.

Parvez, A. (2017). How a spring revival scheme in India's Sikkim is defeating droughts. Gangtok, India: Inter Press Service. http://www. ipsnews.net/2017/02/how-a-spring-revival-scheme-in-indias-sikkim-isdefeating-droughts/.

People's Republic of China. (2015). Intended nationally determined contributions-China. Beijing: National Development and Reform Commission. http://www4.unfccc.int/ndcregistry/PublishedDocum ents/China\%20First/China\%27s\%20First\%20NDC\%20Submission. pdf.

Roy, J. (2000). The rebound effect: Some empirical evidence from India. Energy Policy, 28(6), 433-438.

Royal Government of Bhutan. (2013). SAARC development goalsBhutan Country Report. Bhutan: Gross National Happiness Commission. http://www.indiaenvironmentportal.org.in/files/file/SDGCountry-report-Bhutan-2013.pdf.

Royal Government of Bhutan. (2015). Intended nationally determined contributions-Bhutan. Thimphu: National Environment Commission. http://www4.unfccc.int/ndcregistry/PublishedDocuments/ Bhutan\%20First/Bhutan-INDC-20150930.pdf.

SAARC (2016). The South Asian Free Trade Area (SAFTA), 12th SAARC summit, Islamabad, Pakistan, http://saarc-sec.org/digital_ library/detail_menu/agreement-on-south-asian-free-trade-area-safta.

Sorrell, S., Dimitropoulos, J., \& Sommerville, M. (2009). Empirical estimates of the direct rebound effect: A review. Energy Policy, 37 (4), 1356-1371.

The People's Republic of China. (2016). China's national plan on implementation of the 2030 agenda for sustainable development. The People's Republic of China, Beijing: Ministry of Foreign Affairs. http://www.fmprc.gov.cn/web/ziliao_674904/zt_674979/ dnzt_674981/qtzt/2030kcxfzyc_686343/ P020170414689023442403.pdf.

The Republic of the Union of Myanmar. (2015). Intended nationally determined contributions-Myanmar. Nay Pyi Taw: Ministry of
Environment Conservation and Forestry. http://www4.unfccc.int/ ndcregistry/PublishedDocuments/Myanmar\%20First/Myanmar\% 27s\%20INDC.pdf.

The World Bank. (2010). Trading Economics data. Gross er 111.8 https://tradingeconomics.com/bangladesh/school-enrollment-primar y-percent-gross-wb-data.html.

The World Bank. (2010). https://data.worldbank.org/indicator/SH.STA. STNT.ZS? locations $=\mathrm{CN}$.

The World Bank. (2012). http://povertydata.worldbank.org/poverty/ country/CHN.

The World Bank. (2013). Life expectancy at birth, total, India. https:// data.worldbank.org/indicator/SP.DYN.LE00.IN.

The World Bank Data. (2013). https://data.worldbank.org/indicator/EG. ELC.ACCS.ZS.

The World Bank. (2014). Food exports (\% of merchandise exports), Asia Pacific Region. https://data.worldbank.org/indicator/TX.VAL. FOOD.ZS.UN.

The World Bank. (2016). Population, total. https://data.worldbank.org/ indicator/SP.POP.TOTL.

UNEP. (1997). Global environmental outlook 1. United Nations Environment Program Global State of the Environment Report 1997. Hertfordshire, United Kingdom: SMI Books.

UNEP. (1999). Global environmental outlook 2000. United Nations Environment Program, Nairobi, Kenya.

UNEP. (2002). Global environmental outlook 2000. United Nations Environment Program, Nairobi, Kenya.

UNEP. (2007). Global environmental outlook 4. United Nations Environment Program, Nairobi, Kenya.

UNEP. (2012). Global environmental outlook 5. Environment for the future we want. United Nations Environment Program, Nairobi, Kenya.

UNICEF Report. (2013). https://in.reuters.com/article/health-nutritionunicef/about-48-percent-of-children-in-india-are-stunted-unicefidINDEE95607N20130607.

World Data Atlas. (2013). https://knoema.com/atlas.

World Economic Forum. (2014). Gender gap index of India. The Global Gender Gap Report, Switzerland. http://reports.weforum. org/global-gender-gap-report-2014/economies/\#economy=IND.
Open Access This chapter is licensed under the terms of the Creative Commons Attribution 4.0 International License (http:// creativecommons.org/licenses/by/4.0/), which permits use, sharing, adaptation, distribution and reproduction in any medium or format, as long as you give appropriate credit to the original author(s) and the source, provide a link to the Creative Commons license and indicate if changes were made.
The images or other third party material in this chapter are included in the chapter's Creative Commons license, unless indicated otherwise in a credit line to the material. If material is not included in the chapter's Creative Commons license and your intended use is not permitted by statutory regulation or exceeds the permitted use, you will need to obtain permission directly from the copyright holder. 